
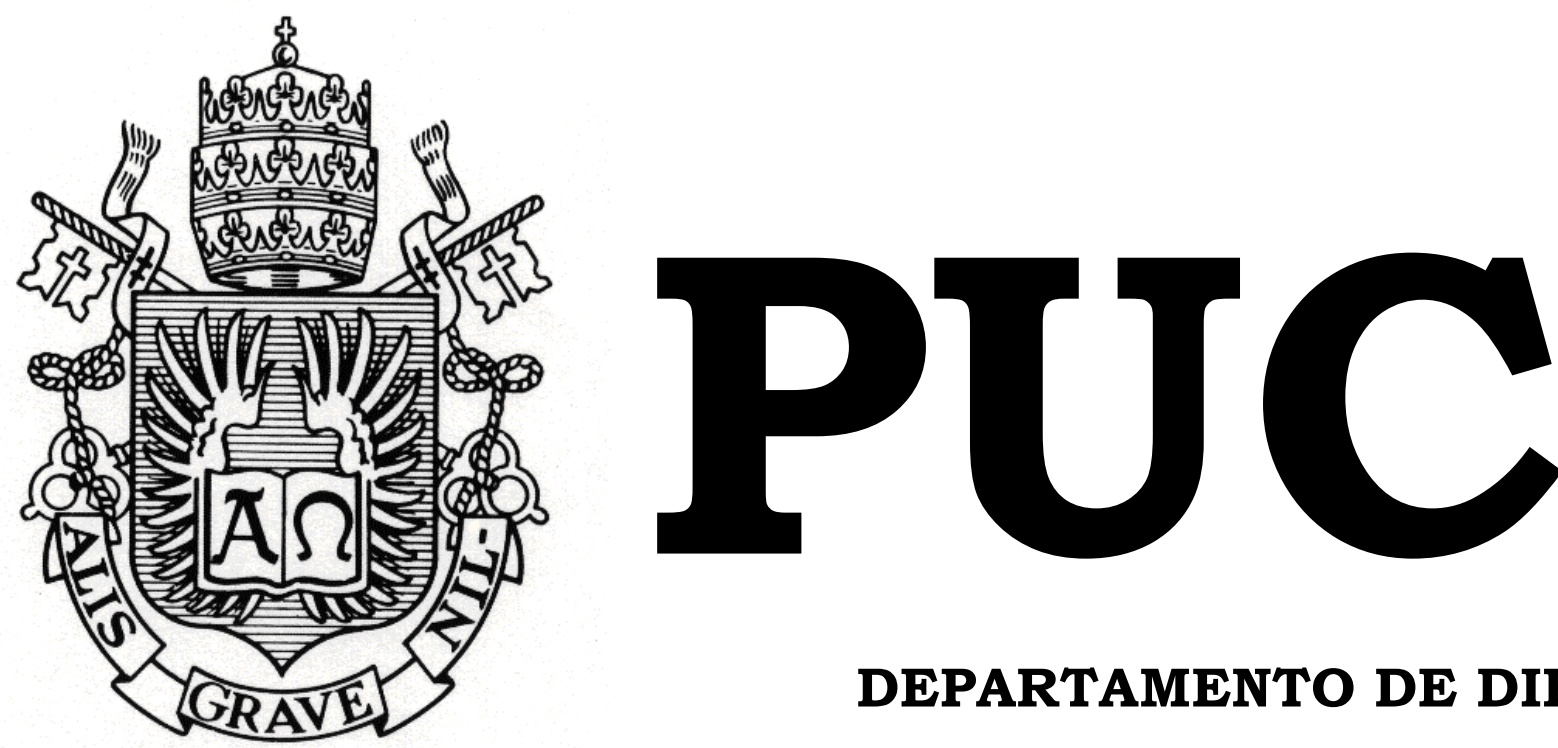

DEPARTAMENTO DE DIREITO

IMPOSTO DE RENDA SOBRE LUCROS OBTIDOS POR CONTROLADAS E COLIGADAS NO EXTERIOR

por

BRUNO DE MENEZES ALVES

ORIENTADOR: GUSTAVO JUNQUEIRA CARNEIRO LEÃO 2013.2

PONTIFÍCIA UNIVERSIDADE CATÓLICA DO RIO DE JANEIRO RUA MARQUÊS DE SÃO VICENTE, 225 - CEP 22453-900 RIO DE JANEIRO - BRASIL 


\title{
IMPOSTO DE RENDA SOBRE LUCROS OBTIDOS POR CONTROLADAS E COLIGADAS NO EXTERIOR
}

\author{
por
}

\section{BRUNO DE MENEZES ALVES}

Monografia apresentada ao Departamento de Direito da Pontifícia Universidade Católica do Rio de Janeiro (PUC-Rio) para a obtenção do Título de Bacharel em Direito.

Orientador: Gustavo Junqueira Carneiro Leão 
Dedicatória

Dedico este trabalho a Nilza. 


\section{Agradecimentos}

Agradeço, primeiramente, ao Professor Gustavo Junqueira, orientador deste trabalho. Tive meu primeiro contato com a área tributária com Gustavo quando ainda era estagiário e trabalhávamos em uma Multinacional. Quis o destino que nos reencontrássemos anos depois na PUC-Rio, onde cursei diversas matérias das quais ele era professor.

Agradeço aos meus familiares, principalmente minha mãe e meu pai, pelo apoio nestes anos de faculdade. Agradeço, especialmente, a Luiza pelo apoio incondicional, pelos conselhos e pela alegria que me dá diariamente.

Agradecimentos também ao meu irmão Daniel, meus amigos e sócios.

Bruno de Menezes Alves 


\section{Resumo}

O objetivo do presente trabalho é abordar a incidência do Imposto de Renda devido pela pessoa jurídica sobre os lucros auferidos por sociedades controladas e coligadas no exterior. Serão abordadas questões como: a evolução da legislação pertinente ao tema e princípios aplicáveis; a experiência internacional sobre a matéria; conceitos de controladas e coligadas; e aspectos societários e contábeis relativos às investidoras e investidas. Por fim, será discutida a suposta inconstitucionalidade da Medida Provisória $n^{\circ}$ 2.158/2001, além dos posicionamentos do Conselho Administrativo de Recursos Fiscais (CARF) e do Supremo Tribunal Federal (STF) acerca do tema.

Palavras Chave: Direito Tributário - Imposto de Renda - Lucros auferidos no Exterior - Coligadas e Controladas - Princípios da Territorialidade e Universalidade - Resultado de Equivalência Patrimonial - Disponibilidade Jurídica e Econômica - Inconstitucionalidade 


\section{Sumário}

INTRODUÇÃO

CAPÍTULO I - A LEGISLAÇÃO BRASILEIRA E OS PRINCÍPIOS

E CONCEITOS DE TRIBUTAÇÃO DA RENDA NO PAÍS............. 10

1.1. Lei $n^{\circ}$ 9.249/95 e o Sistema de Tributação da Renda Global....................... 10

1.2. Código Tributário Nacional, a Lei $n^{\circ} 9.532 / 97$ e a Disponibilidade............. 12

1.3. O Controle do Fato Gerador por parte das Sociedades Investidoras, a Lei Complementar $n^{\circ} 104 / 2001$ e o art. 74 da Medida Provisória $n^{\circ} 2.158$ $35 / 2001$

\section{CAPÍTULO II - A TRANSPARÊNCIA FISCAL INTERNACIONAL}

2.1. CFC Rules 18

2.2. Distinções entre os Sistemas de Transparência Fiscal Internacionais e o Ordenamento Jurídico Brasileiro

\section{CAPÍTULO III - DO CONCEITO DE SOCIEDADES}

3.1. Conceitos de Controladas e Coligadas .........................................................2 22

3.2. Investimentos Relevantes e conceitos da legislação fiscal ......................... 24

\section{CAPÍTULO IV - DO MÉTODO DE EQUIVALÊNCIA}

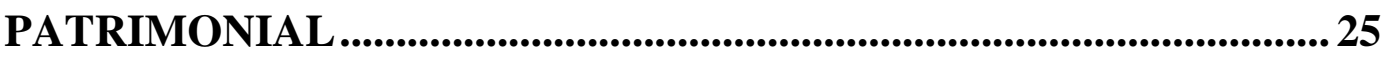

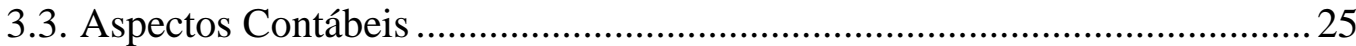

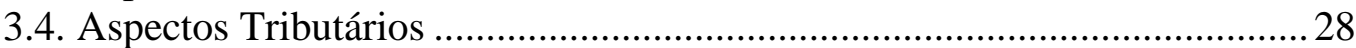

CAPÍTULO V - OUTROS ASPECTOS .................................................... 30

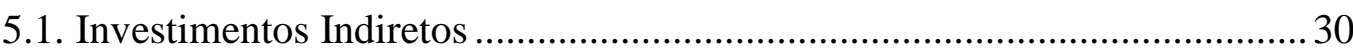

5.2. Cálculo e Compensação do Imposto de Renda Devido no Brasil................. 33

CAPÍTULO VI - JURISPRUDÊNCIA E CRÍTICA DOUTRINÁRIA 35

6.1. Separação Patrimonial Entre Pessoas Jurídicas ........................................... 35

6.2. Violação do Conceito Constitucional de Renda ......................................... 38

6.3. A Compatibilidade do art. 74 da MP 2.158 com as Convenções Para Evitar a Dupla Tributação (CDT) ........................................................................... 43

CAPÍTULO VII - CONSIDERAÇÕES FINAIS .................................... 48

BIBLIOGRAFIA 


\section{Lista de Abreviações}

ADI:

Art.:

CRFB

CSLL:

CTN:

IN:

IRPJ:

MP:

RE:

RFB:

SRF:
Ação Declaratória de

Inconstitucionalidade

Artigo

Constituição da República

Federativa do Brasil de 1988

Contribuição Social sobre o Lucro

Líquido

Lei n ${ }^{\circ}$ 5.172/1966 (Código

Tributário Nacional)

Instrução Normativa

Imposto de Renda das Pessoas

Jurídicas

Medida Provisória

Recurso Extraordinário

Receita Federal do Brasil

Secretaria da Receita Federal 


\section{Introdução}

O processo de abertura e integração comercial ocorrido na década de 90 no Brasil originou um crescimento intenso não somente dos investimentos estrangeiros no país, mas, também, dos investimentos de empresas brasileiras no exterior.

Aliado à alta carga tributária incidente sobre a renda no Brasil, este fenômeno fez com que empresas brasileiras buscassem mecanismos para reduzir ou diferir a tributação sobre seus resultados, por meio da constituição de grupos empresariais internacionais ${ }^{1}$. Nestes grupos, as sociedades brasileiras investem em outras empresas estrangeiras sediadas em países com tributação favorecida.

No intuito de suprimir a prática de planejamento tributário de empresas brasileiras envolvendo sociedades investidas no exterior, o ordenamento jurídico brasileiro passa a adotar, a partir da edição da Lei $n^{\circ}$ 9.249/95, o princípio da universalidade. Isto faz com que o Imposto de Renda incida sobre os lucros das pessoas jurídicas auferidos no território brasileiro e também no exterior.

O regime universal de tributação da renda também é adotado por outros países, como Estados Unidos, Alemanha, Reino Unido e Japão ${ }^{2}$.

A partir da edição da Lei $n^{\circ} 9.249 / 95$ até o presente momento a legislação pertinente ao Imposto de Renda sobre lucros de coligadas e controladas no exterior previu diferentes momentos para a tributação. Atualmente, os lucros auferidos por sociedades coligadas e controladas no exterior são considerados disponíveis à sociedade investidora brasileira na data do balanço no qual estes lucros tiverem sido apurados, conforme o art.

\footnotetext{
${ }^{1}$ GRECO, Marco Aurélio; ROCHA, Sergio André. Manual de Direito Tributário Internacional. São Paulo: Dialética, 2012, p. 388.

${ }^{2}$ TÔRRES, Heleno Taveira. Tributação de controladas e coligadas no exterior. São Paulo:

Fiscosoft, 2012.
} 
74 da MP no 2.158-34/2001, ainda que estes lucros não venham a ser distribuídos.

Esta previsão legal, além de se diferenciar dos mecanismos adotados pelos países estrangeiros no controle dos métodos de transparência fiscal $^{3}$ (como veremos a seguir), ofende conceitos como o de renda e separação patrimonial.

${ }^{3}$ GRECO, Marco Aurélio; ROCHA, Sergio André. Manual de Direito Tributário Internacional. São Paulo: Dialética, 2012, p. 388. 


\section{CAPÍTULO I - A Legislação Brasileira e os Princípios e Conceitos de Tributação da Renda no País}

Neste capítulo, será demonstrada a evolução da legislação brasileira concernente à tributação dos lucros auferidos por coligadas e controladas no exterior, além dos princípios e conceitos conexos ao tema.

\subsection{Lei no 9.249/95 e o Sistema de Tributação da Renda Global}

Até o início da vigência da Lei $n^{\circ}$ 9.249/95, o ordenamento jurídico brasileiro adotava o princípio da territorialidade, sistema no qual eram tributados os lucros auferidos no Brasil por residentes. Desta forma, a renda auferida fora do território nacional ${ }^{4}$ por residentes estaria fora da incidência do Imposto de Renda no Brasil.

Acerca do princípio da territorialidade, versa TÔRRES ${ }^{5}$ :

"Do princípio da territorialidade dessome-se o alcance espacial das normas tributárias sobre os fatos juridicizados pelo ordenamento, o que estabelece uma reserva de exclusividade para a aplicação das leis do Estado aos fatos ocorridos neste espaço (...) promovidos por residentes ou não-residentes"

Ainda sobre o referido princípio, XAVIER $^{6}$ esmiúça o âmbito de incidência do Imposto de Renda:

"De harmonia com o princípio da territorialidade, anteriormente vigente no Brasil, nenhuma renda cuja fonte de produção se localize no exterior

\footnotetext{
4 “Os limites territoriais entre os Estados são estabelecidos juridicamente. Sem a ordem jurídica o território não existiria, e muito menos o efeito de "territorialidade". Por isso que só é possível falarmos em "território" como espaço físico juridicamente qualificado e delimitado, e, por conseguinte, imprescindível à noção de Estado de Direito, como elemento basilar deste". TÔRRES, Heleno Taveira. Princípio da Territorialidade e tributação de não-residentes no Brasil. Prestações de serviços no exterior. Fonte de produção e fonte de pagamento. In: TÔRRES, Heleno Taveira. Direito tributário internacional aplicado. São Paulo: Quartier Latin, 2003, p. 77.

${ }^{5}$ TÔRRES, Heleno Taveira. Tributação de controladas e coligadas no exterior. São Paulo: Fiscosoft, 2012.

${ }^{6}$ XAVIER, Alberto. A tributação dos lucros de controladas e coligadas de empresas brasileiras no exterior e os tratados contra a dupla tributação. In: Revista Tributária e de Finanças Públicas, $n^{\circ} 3$, ano 3. Almedina, 2010, p. 12.
} 
recai no âmbito de incidência do imposto de renda das pessoas jurídicas: nem a renda obtida diretamente através de uma atividade funcional (o exercício do próprio objeto social) ou de uma atividade jurídica (o exercício de direitos a rendimentos, tais como juros, royalties e dividendos), nem a renda obtida indiretamente através de uma organização de pessoas e bens localizada no exterior, quer se trate de filiais ou sucursais, sem personalidade jurídica, quer se trate de sociedades controladas ou coligadas, com individualidade jurídica própria."

Como efeito da globalização da economia, os Estados começaram a concentrar seus esforços na obtenção de mecanismos para tributar eventos ocorridos fora de seus limites territoriais. O intuito dos Estados era o de cercar estruturas internacionais utilizadas pelas empresas para reduzir a carga tributária por elas suportadas.

Acerca destas estruturas lecionam Marco Aurélio Greco e Sérgio André Rocha:

"Um dos mecanismos de que se valem as empresas para atingir tais objetivos é a constituição de grupos empresariais internacionais, com a interposição de empresas situadas em países com tributação favorecida, buscando, dessa forma, elidir ou tão somente diferir a imposição fiscal que, de outra forma, incidiria diretamente sobre os resultados auferidos no exterior.",

O sistema de tributação da renda global (pautado no princípio da universalidade), portanto, permite que o Estado Brasileiro possa tributar rendimentos auferidos por residentes brasileiros no exterior, buscando coibir práticas tributárias elisivas ${ }^{8}$.

Sobre o princípio da universalidade, $\mathrm{XAVIER}^{9}$ leciona:

"No polo oposto ao princípio da territorialidade situa-se o princípio da universalidade (ou do world-wide-income), segundo o qual toda a renda da pessoa jurídica deve ser tributada no país de domicílio, incluindo a renda externa, seja esta decorrente de atividade funcional ou jurídica, seja

\footnotetext{
${ }^{7}$ GRECO, Marco Aurélio; ROCHA, Sergio André. Manual de Direito Tributário Internacional. São Paulo: Dialética, 2012, p. 388.

8 "Planejamento é a atividade exercida pelo contribuinte, enquanto elisão é o efeito de submeter-se a uma menor carga tributária, obtido pelo planejamento." GRECO, Marco Aurélio. Planejamento Tributário. São Paulo: Dialética, 2004, p. 11.

${ }^{9}$ XAVIER, Alberto. A tributação dos lucros de controladas e coligadas de empresas brasileiras no exterior e os tratados contra a dupla tributação. In: Revista Tributária e de Finanças Públicas, $n^{\circ} 3$, ano 3. Almedina, 2010, p. 12.
} 
esta obtida através de filiais ou de subsidiárias. No que respeita às subsidiárias, com personalidade jurídica própria, a lógica do princípio da universalidade conduz à tributação dos dividendos por esta distribuídos, que são renda efetiva da sociedade controladora, mas não dos lucros acumulados ou retidos na subsidiária, que são renda própria desta, não tornada disponível para a controladora. Este é o sistema adotado, via de regra, pela generalidade dos países mais desenvolvidos.”

Inicialmente, a tributação dos lucros, rendimentos e ganhos de capital obtidos no exterior foi estabelecida pelos arts. 25 e 27 da Lei $n^{\circ}$ $9.249 / 95$

"Art. 25. Os lucros, rendimentos e ganhos de capital auferidos no exterior serão computados na determinação do lucro real das pessoas jurídicas correspondente ao balanço levantado em 31 de dezembro de cada ano."

Pode-se notar (e essa análise será de suma importância mais a frente) que o enunciado do caput do art. 25 não dá detalhes acerca da destinação ou disponibilidade dos lucros obtidos no exterior alvo de tributação no Brasil. ANDRADE FILHO faz tal observação:

"O art. 25 da Lei $\mathrm{n}^{\mathrm{o}}$ 9.249/95 estabeleceu que a regra impositiva alcançasse o lucro apurado pelas sociedades investidas no exterior independentemente de terem sido distribuídos ou pagos." 10

\subsection{Código Tributário Nacional, a Lei no $\quad 9.532 / 97$ e Disponibilidade}

À época da edição da lei $n^{\circ}$ 9.249/95, o exposto no art. 25 violava veementemente a previsão do art. 43 do Código Tributário Nacional $(\mathrm{CTN})^{11}$ quanto ao fato gerador do Imposto de Renda:

"Art. 43. O imposto, de competência da União, sobre a renda e proventos de qualquer natureza tem como fato gerador a aquisição da disponibilidade econômica ou jurídica:

I - de renda, assim entendido o produto do capital, do trabalho ou da combinação de ambos;

${ }^{10}$ ANDRADE F, Edmar Oliveira. Imposto de Renda das Empresas. São Paulo: Atlas, 2013, p. 507.

${ }^{11} \mathrm{O}$ art. 43 do CTN reflete o art. 153, III da CRFB: "Art. 153. Compete à União instituir impostos sobre: (...) III - renda e proventos de qualquer natureza;”. 
II - de proventos de qualquer natureza, assim entendidos os acréscimos patrimoniais não compreendidos no inciso anterior."

De acordo com o art. 43 do CTN, o Imposto de Renda recairá sobre a renda ou proventos de qualquer natureza. Não havendo acréscimos patrimoniais ou aquisição de renda, considerando que os lucros da coligada ou controlada no exterior não tenham sido distribuídos, não há do que se falar de tributação de renda não disponível à pessoa jurídica investidora brasileira.

Acerca dos conceitos de "disponibilidade econômica ou jurídica", MACHADO elucida:

"Entende-se por disponibilidade econômica a possibilidade de dispor, possibilidade de fato, material, direta, da riqueza. Possibilidade de direito e de fato, que se caracteriza pela posse livre e desembaraçada da riqueza. Configura-se pelo efetivo recebimento da renda ou dos proventos. Como assevera Gomes de Sousa, na linguagem de todos os autores que tratam do assunto, disponibilidade econômica corresponde a rendimento (ou provento) realizado, isto é, dinheiro em caixa." 12

"A disponibilidade econômica decorre do recebimento do valor que se vem a acrescentar o patrimônio do contribuinte. Já a dispobilidade jurídica decorre do simples crédito desse valor, do qual o contribuinte passa a juridicamente dispor, embora este não lhe esteja ainda nas mãos."

Em dezembro de 1997, foi convertida na lei $\mathrm{n}^{\circ}$ 9.532/97 a Medida Provisória $\mathrm{n}^{\mathrm{o}}$ 1.602/97. A referida lei trouxe um conjunto de regras já anteriormente trazidas pela Instrução Normativa SRF n ${ }^{\circ}$ 38/96.

"Art. $1^{\circ}$ Os lucros auferidos no exterior, por intermédio de filiais, sucursais, controladas ou coligadas serão adicionados ao lucro líquido, para determinação do lucro real correspondente ao balanço levantado no dia 31 de dezembro do ano-calendário em que tiverem sido disponibilizados para a pessoa jurídica domiciliada no Brasil.”

Em relação ao texto da IN SRF no 38/96, a lei no $9.532 / 97$ prevê que os lucros das sociedades controladas ou coligadas estrangeiras seriam

\footnotetext{
${ }^{12}$ MACHADO, Hugo de Brito. Comentários ao Código Tributário Nacional. $2^{\mathrm{a}}$ ed.. São Paulo: Atlas, 2007, p. 448.

${ }^{13}$ MACHADO, Hugo de Brito. Curso de Direito Tributário. 29a ed.. São Paulo: Malheiros, 2008. p. 315 .
} 
considerados disponibilizados à sociedade investidora brasileira "na data do pagamento ou do crédito em conta representativa de obrigação da empresa no exterior" $" 14$.

O próprio parágrafo $2^{\circ}$ do art. $1^{\circ}$ da lei $n^{\circ} 9.532 / 97$ determina o que representaria a expressão "pagamento ou crédito"15. O lucro seria considerado creditado quando o montante fosse transferido para qualquer conta que representasse um passível exigível por parte da sociedade investidora.

Em 2000 houve uma mudança nas regras acerca do tema. A lei $n^{\circ}$ 9.959/2000 (fruto da conversão em lei da Medida Provisória $n^{\circ}$ 1924/99) acrescentou novas hipóteses de disponibilização dos lucros das coligadas e controladas no exterior ao parágrafo primeiro do art. $1^{\circ}$ da lei $\mathrm{n}^{\circ}$ 9.532/97:

"Art. $3^{\circ} \mathrm{O}$ art. $1^{\circ}$ da Lei $\mathrm{n}^{\circ}$ 9.532, de 1997, passa a vigorar com a seguinte redação:

"Art. $1^{\circ}$

$\S 1^{\circ}$

c) na hipótese de contratação de operações de mútuo, se a mutuante, coligada ou controlada, possuir lucros ou reservas de lucros;

d) na hipótese de adiantamento de recursos, efetuado pela coligada ou controlada, por conta de venda futura, cuja liquidação, pela remessa do bem ou serviço vendido, ocorra em prazo superior ao ciclo de produção do bem ou serviço."”

\footnotetext{
${ }^{14}$ Art. $1^{\circ}, \S 1^{\text {o }}$ " "b" da lei $n^{\circ} 9.532 / 97$.

15 “Art. $1^{\circ}$. (...) $\$ 2^{\circ}$ Para efeito do disposto na alínea "b" do parágrafo anterior, considera-se: a) creditado o lucro, quando ocorrer a transferência do registro de seu valor para qualquer conta representativa de passivo exigível da controlada ou coligada domiciliada no exterior; b) pago o lucro, quando ocorrer:

1. o crédito do valor em conta bancária, em favor da controladora ou coligada no Brasil;

2. a entrega, a qualquer título, a representante da beneficiária;

3. a remessa, em favor da beneficiária, para o Brasil ou para qualquer outra praça;

4. o emprego do valor, em favor da beneficiária, em qualquer praça, inclusive no aumento de capital da controlada ou coligada, domiciliada no exterior."
} 
Até este momento, como nos ensina ANDRADE FILHO 16 , "sempre tivemos claro que a disponibilização que determinava o cômputo do valor do lucro na determinação do lucro real do contribuinte investidor seria aquela decorrente de ato societário regular que determinasse a distribuição dos lucros".

\subsection{O Controle do Fato Gerador por parte das Sociedades Investidoras, a Lei Complementar no 104/2001 e o art. 74 da Medida Provisória no 2.158-35/2001}

Ante o exposto, podemos verificar que o Estado Brasileiro buscou coibir o planejamento tributário internacional com a adoção do princípio da universalidade que ampliaria o rol de tributação do Imposto de Renda sobre os lucros auferidos por sociedades controladas e coligadas no exterior. Até o ano 2000, a legislação sobre a matéria determinava que os lucros a serem atingidos pela tributação do Imposto de Renda seriam aqueles montantes efetivamente distribuídos ou disponibilizados à sociedade investidora.

GRECO e ROCHA, sobre a insuficiência arrecadatória do conjunto de regras à época:

"Diante desse quadro, era possível que as empresas localizadas em território nacional, controladoras de outras situadas no exterior, coordenassem o momento em que tal disponibilidade se verificaria e, portanto, o instante em que o fato gerador do Imposto sobre a Renda se consumaria." 17

Para que estes mecanismos de controle do fato gerador do Imposto de Renda fossem utilizados pela sociedade investidora para se diferir a

\footnotetext{
${ }^{16}$ ANDRADE F, Edmar Oliveira. Imposto de Renda das Empresas. São Paulo: Atlas, 2013, p. 521.

${ }^{17}$ GRECO, Marco Aurélio; ROCHA, Sergio André. Manual de Direito Tributário Internacional. São Paulo: Dialética, 2012, p. 388.
} 
tributação no Brasil, a Lei Complementar no 104/2001 veio a inserir o parágrafo $2^{\circ}$ ao art. 43 do $\mathrm{CTN}$ :

“Art. 43. (...)

$\S 2$ o Na hipótese de receita ou de rendimento oriundos do exterior, a lei estabelecerá as condições e o momento em que se dará sua disponibilidade, para fins de incidência do imposto referido neste artigo."

Com fundamento no novo parágrafo $2^{\circ}$ do art. 43 do CTN, a Medida Provisória $n^{\circ} 2.158 / 2001$, em seu artigo 74, determinou que os lucros auferidos por controlada ou coligada no exterior seriam considerados automaticamente disponibilizados na data do balanço em que tenham sido apurados.

"Art. 74. Para fim de determinação da base de cálculo do imposto de renda e da CSLL, nos termos do art. 25 da Lei $n^{\circ}$ 9.249, de 26 de dezembro de 1995, e do art. 21 desta Medida Provisória, os lucros auferidos por controlada ou coligada no exterior serão considerados disponibilizados para a controladora ou coligada no Brasil na data do balanço no qual tiverem sido apurados, na forma do regulamento.

Parágrafo único. Os lucros apurados por controlada ou coligada no exterior até 31 de dezembro de 2001 serão considerados disponibilizados em 31 de dezembro de 2002, salvo se ocorrida, antes desta data, qualquer das hipóteses de disponibilização previstas na legislação em vigor."

\section{ANDRADE FILHO sobre o preceito trazido pela Medida Provisória} $n^{\circ} 2.158$ :

"Esse preceito, a rigor, equipara uma sociedade coligada ou controlada a uma filial ou sucursal, de modo que a tributação ocorre no momento em que os lucros são apurados independentemente da distribuição efetiva ou por equiparação." 18

Posteriormente, foi editada a Instrução Normativa SRF no 213/2002 que trouxe normas técnicas relativas ao art. 74 da MP n ${ }^{\circ} 2 \cdot 158 / 2001$. A IN 213/2002 trouxe em seu art. $7^{\circ}$ a previsão de cômputo dos resultados

\footnotetext{
${ }^{18}$ ANDRADE F, Edmar Oliveira. Imposto de Renda das Empresas. São Paulo: Atlas, 2013, p.
} 522. 
positivos da equivalência patrimonial (método que reflete as variações nos investimentos da sociedade investidora nas investidas, como veremos a seguir) na determinação do lucro real da sociedade investidora brasileira.

“Art. $7^{\circ}$ A contrapartida do ajuste do valor do investimento no exterior em filial, sucursal, controlada ou coligada, avaliado pelo método da equivalência patrimonial, conforme estabelece a legislação comercial e fiscal brasileira, deverá ser registrada para apuração do lucro contábil da pessoa jurídica no Brasil.

$\S 1^{\circ}$ Os valores relativos ao resultado positivo da equivalência patrimonial, não tributados no transcorrer do ano-calendário, deverão ser considerados no balanço levantado em 31 de dezembro do ano-calendário para fins de determinação do lucro real e da base de cálculo da CSLL."

De acordo com XAVIER, há atualmente no Brasil um sistema de tributação que extrapola o princípio da universalidade no que tange ao alcance da incidência do Imposto de Renda sobre rendimentos obtidos no exterior:

"É importante salientar que este sistema de tributação vai mais longe que o princípio da universalidade, na pureza dos seus contornos, pois manda adicionar ao lucro da sociedade domiciliada no Brasil a totalidade do lucro obtido pelas controladas ou coligadas no exterior, na proporção da participação no capital social destas, ainda que tais lucros tenham sido integralmente retidos e não distribuídos. Assim sendo, o imposto brasileiro atingiria renda que não é da própria sociedade brasileira, mas renda de titularidade jurídica de sociedades estrangeiras independentes. Trata-se, portanto, de um sistema de "universalidade ampliada" de tributação extraterritorial." 19

\footnotetext{
${ }^{19}$ XAVIER, Alberto. A tributação dos lucros de controladas e coligadas de empresas brasileiras no exterior e os tratados contra a dupla tributação. In: Revista Tributária e de Finanças Públicas, nº 3 , ano 3. Almedina, 2010, p. 14.
} 


\section{CAPÍTULO II - A Transparência Fiscal Internacional}

Neste capítulo, pretende-se abordar os aspectos gerais das medidas antielisivas adotadas no âmbito tributário internacional e as diferenças destas medidas ao ordenamento jurídico brasileiro.

\subsection{CFC Rules}

A adoção de práticas antielisivas baseadas na retenção dos lucros auferidos por sociedades controladas no exterior teve início na década de 1930 nos Estados Unidos ${ }^{20}$. Estas práticas, décadas depois, configuraram-se nas regras de Controlled Foreign Corporation (CFC). Criadas em 1962, as CFC Rules tiveram como primeiro objetivo a redução do déficit fiscal dos EUA. O Governo da época considerava a medida antielisiva como mecanismo efetivo no combate ao diferimento da tributação promovido por investimentos de sociedades norte-americanas no exterior ${ }^{21}$.

Segundo TÔRRES, "o regime de $C F C$ - legislation, funcionalmente, permite imputar aos sócios ou acionistas residentes os lucros produzidos pela sociedade constituída e localizada em países com tributação favorecida, com incidência do imposto aplicável aos lucros produzidos no exterior automaticamente, como se fossem produzidos internamente, mesmo que não distribuídos sob a forma de "dividendos", sempre que presentes alguns pressupostos de controle antielusivo"22.

Note-se que as regras de CFC têm o objetivo de controlar medidas fiscais abusivas por parte das sociedades que possuem investimentos

\footnotetext{
${ }^{20}$ TORRES, Ricardo Lobo. Planejamento Tributário - Elisão Abusiva e Evasão Fiscal. São Paulo: Elsevier, 2012, p. 67.

${ }^{21}$ PEREIRA, Roberto Codorniz Leite. O regime brasileiro de tributação de lucros auferidos por controladas e coligadas no exterior: um estudo empírico sobre as suas causas e efeitos. Mestrado em Direito na Escola de Direito de São Paulo da Fundação Getulio Vargas. São Paulo, 2012. p. 33. ${ }^{22}$ TÔRRES, Heleno Taveira. Tributação de controladas e coligadas no exterior. São Paulo: Fiscosoft, 2012.
} 
estrangeiros almejando o diferimento ou redução de sua carga tributária global. Neste sentido, GRECO e ROCHA:

“(...) tais regimes (transparência fiscal internacional) não são utilizados como regra geral de tributação, como se passa no Brasil, mas como regimes excepcionais de controle de evasão fiscal ou de planejamentos fiscais abusivos." 23

Após 1962, a técnica norte-americana do CFC expandiu-se para outros países como a Alemanha, o Reino Unido, França e Espanha ${ }^{24}$. Atualmente, o sistema da CFC é adotado amplamente na comunidade global, dividindo-se em dois métodos de aplicação:

a) Método Global. Adotado pelos Estados Unidos, o método atribui preponderância à natureza do rendimento obtido pela controlada, pretendendo alcançar imediatamente certas classes de renda, especialmente os "rendimentos passivos" (e.g. dividendos, royalties, juros, lucros), independentemente do local de domicílio da sociedade intermediária ${ }^{25}$.

b) Método de Jurisdição designada. Adotado em países como o Japão, França e Reino Unido, este método possui foco na tributação de acionistas de sociedades controladas localizadas em países de baixa tributação.

No entanto, XAVIER esclarece que atualmente os métodos de sistema CFC não se atêm necessariamente às características próprias de cada modelo:

"A verdade, porém, é que tanto as legislações que se inspiraram num modelo quanto no outro acabaram por se influenciar reciprocamente com vistas a aperfeiçoar os seus mecanismos, de tal modo que hoje é

\footnotetext{
${ }^{23}$ GRECO, Marco Aurélio; ROCHA, Sergio André. Manual de Direito Tributário Internacional. São Paulo: Dialética, 2012, p. 390.

${ }^{24}$ TORRES, Ricardo Lobo. Planejamento Tributário - Elisão Abusiva e Evasão Fiscal. São Paulo: Elsevier, 2012, p. 67.

${ }^{25}$ XAVIER, Alberto. A tributação dos lucros de controladas e coligadas de empresas brasileiras no exterior e os tratados contra a dupla tributação. In: Revista Tributária e de Finanças Públicas, $n^{\circ} 3$, ano 3. Almedina, 2010, p. 14.
} 
praticamente impossível descortinar um caso que obedeça, na sua pureza, a um tipo único. Assim, a tendência predominante é de as legislações "CFC" atingirem os rendimentos passivos auferidos por sociedades controladas instaladas em território de baixa tributação." ${ }^{26}$

Por fim, ROCHA conclui sobre os sistemas de transparência fiscal internacional:

"De tudo que foi aduzido no presente item, pode-se inferir que as regras de transparência fiscal internacional são um instrumento utilizado para coibir a evasão fiscal e os planejamentos fiscais abusivos, notadamente aqueles que se perfazem com a utilização de empresas residentes em países com tributação favorecida, não cabendo falar de sua aplicação quando a empresa não residente estiver sediada em país que tribute a renda em níveis normais, de acordo com o previsto na legislação, realizando empreendimentos econômicos ativos, ou quando a pessoa jurídica residente não tenha controle da empresa estabelecida no exterior."

\subsection{Distinções entre os Sistemas de Transparência Fiscal Internacionais e o Ordenamento Jurídico Brasileiro}

Ante o exposto nos capítulos anteriores, as regras CFC adotadas em países como os Estados Unidos, Alemanha e Reino Unido são medidas que normalmente não abrangem a totalidade das rendas auferidas pelas controladas no exterior. Estes Estados também não adotam medidas antielisivas perante todas as sociedades não residentes cujo controle é exercido por empresas nacionais.

Por outro lado, a legislação tributária brasileira vigente acaba por não discriminar os lucros auferidos no exterior, quanto mais quais as sociedades que estarão sujeitas à tributação.

Acerca das diferenças entre os sistemas de CFC internacionais e o adotado no Brasil, XAVIER observa:

"A lei brasileira, em matéria de sociedades controladas e coligadas no exterior, adotou um sistema que se afasta do tipo CFC, de caráter

\footnotetext{
${ }^{26}$ XAVIER, Alberto. A tributação dos lucros de controladas e coligadas de empresas brasileiras no exterior e os tratados contra a dupla tributação. In: Revista Tributária e de Finanças Públicas, nº 3 , ano 3. Almedina, 2010, p. 19.
} 
excepcional e finalidade antielisiva, pois pretende atingir a totalidade do lucro das sociedades controladas ou coligadas no exterior, independente da natureza dos rendimentos que o integram e do nível de tributação do país ou território de seu domicílio. Falta-lhe, pois, o elemento antielisivo e o caráter de providência excepcional, em relação ao regime geral de tributação de controladas e coligadas, que supõe a distribuição de resultados.

A total inexistência de um elemento "abusivo" relacionado ou com o território de domicílio ou com a natureza do rendimento leva mesmo a afirmar que não se trata de uma lei "CFC".,"27

No intuito de sintetizar as diferenças entre as regras CFC adotadas no âmbito internacional e as medidas adotadas no Brasil, segue abaixo quadro com os principais aspectos de ambos os sistemas.

\begin{tabular}{|c|c|}
\hline CFC Rules & Lei Brasileira $^{28}$ \\
\hline $\begin{array}{c}\text { Tributação voltada para sociedades } \\
\text { controladas por sociedades } \\
\text { residentes }\end{array}{ }^{29} ;$ & $\begin{array}{c}\text { Tributação voltada para sociedades } \\
\text { estrangeiras controladas ou coligadas de } \\
\text { empresas brasileiras; }\end{array}$ \\
\hline $\begin{array}{c}\text { Foco nas CFC localizadas em } \\
\text { países que oferecem baixa } \\
\text { tributação; }\end{array}$ & $\begin{array}{c}\text { Tributação independentemente da } \\
\text { localização da sociedade controlada ou } \\
\text { coligada; }\end{array}$ \\
\hline $\begin{array}{c}\text { Tributação sobre específicas } \\
\text { categorias de rendimentos }\end{array}$ & $\begin{array}{c}\text { Tributação integral dos acréscimos } \\
\text { patrimoniais verificados na sociedade } \\
\text { controlada ou coligada. }\end{array}$ \\
\hline
\end{tabular}

${ }^{27}$ XAVIER, Alberto. A tributação dos lucros de controladas e coligadas de empresas brasileiras no exterior e os tratados contra a dupla tributação. In: Revista Tributária e de Finanças Públicas, ${ }^{\circ} 3$, ano 3. Almedina, 2010, p. 19.

${ }^{28}$ GRECO, Marco Aurélio; ROCHA, Sergio André. Manual de Direito Tributário Internacional. São Paulo: Dialética, 2012, p. 388.

${ }^{29}$ Nos Estados Unidos, por exemplo, são consideradas, em regra geral, Controlled Foreign Corporations aquela empresa não residente que tenha mais de $50 \%$ (cinquenta por cento) de seu capital detido por sócios residentes. Artigo 957, "Internal Revenue Code": "a) General rule For purposes of this subpart, the term "controlled foreign corporation" means any foreign corporation if more than 50 percent of (1) the total combined voting power of all classes of stock of such corporation entitled to vote, or (2) the total value of the stock of such corporation." ${ }^{30}$ TÔRRES, Heleno Taveira. Tributação de controladas e coligadas no exterior. São Paulo: Fiscosoft, 2012. 


\section{CAPÍTULO III - Do conceito de Sociedades Controladas e Coligadas}

\subsection{Conceitos de Controladas e Coligadas}

O investimento que uma Sociedade possui em outra dá ensejo aos conceitos de Sociedades Controladas e Coligadas. O artigo 243 da Lei ${ }^{\circ}$ 6.404/1976 trata dos investimentos de uma Companhia em outras sociedades.

A definição de Sociedades Coligadas encontra-se descrito no parágrafo $1^{\circ}$ do dispositivo.

“Art. 243. O relatório anual da administração deve relacionar os investimentos da companhia em sociedades coligadas e controladas e mencionar as modificações ocorridas durante o exercício.

$\S 1^{\circ}$ São coligadas as sociedades nas quais a investidora tenha influência significativa.

$\S 4^{\circ}$ Considera-se que há influência significativa quando a investidora detém ou exerce o poder de participar nas decisões das políticas financeira ou operacional da investida, sem controlá-la."

Cabe ressaltar que o texto legal que conceituava as sociedades coligadas trazia a condição de que a Sociedade investidora deveria possuir sobre a investida (coligada) ao menos $10 \%$ (dez por cento $)^{31}$. No entanto, atualmente se presume a influência significativa quando a investidora for titular de $20 \%$ (vinte por cento) ou mais do capital votante da investida, sem controlá-la ${ }^{32}$.

Mauricio Moreira Mendonça de Menezes classifica o termo "Influência Relevante" da seguinte forma:

\footnotetext{
${ }^{31}$ A redação do parágrafo $1^{\circ}$ do artigo 243 da Lei $\mathrm{n}^{\circ} 6.404 / 76$ foi alterada pela Lei $\mathrm{n}^{\circ} 11.941 / 2009$.

${ }^{32}$ Art. $243, \S 4^{\circ}$, Lei no $6.404 / 76$.
} 
“(...) quando a participação societária confere a seu titular poderes suficientes para sua intervenção na vida interna da coligada."

No que tange às Sociedades Controladas, o artigo 243 da Lei ${ }^{\circ}$ 6.404/76, em seu parágrafo $2^{\circ}$ traz o seguinte conceito:

“Art. 243. (...)

$\S 2^{\circ}$ Considera-se controlada a sociedade na qual a controladora, diretamente ou através de outras controladas, é titular de direitos de sócio que lhe assegurem, de modo permanente, preponderância nas deliberações sociais e o poder de eleger a maioria dos administradores."

Acerca do conceito de sociedade controlada, Marcelo Cavalcanti Almeida comenta:

"Quando uma sociedade, diretamente ou por meio de outras controladas, é titular de direitos de sócio que lhe assegure, de modo permanente, preponderância nas deliberações sociais e o poder de eleger a maioria dos administradores. É evidente que nesse caso a controladora deve ter, direta ou indiretamente, ações com direito a voto (normalmente representam ações ordinárias). No entanto, para exercer o controle não é necessário que a investidora detenha mais de $50 \%$ das ações com direito a voto. Em certos casos de sociedades investidas com o capital acionário votante pulverizado, mesmo tento, por exemplo, $20 \%$ das ações com direito a voto, a sociedade investidora pode exercer o controle. ${ }^{34}$

Nota-se que o investimento de uma Sociedade no capital social de outra não é, de acordo com a legislação comercial, fator definitivo para que a sociedade investida seja caracterizada como coligada ou controlada. Por outro lado, pode-se inferir que são requisitos mínimos para a definição:

a) de coligada, a participação, por parte da investidora, de $20 \%$ no capital votante da investida, sem poder de controle;

b) de controlada, a participação societária, por parte da investidora, direta ou indireta, além do poder de controle.

\footnotetext{
${ }^{33}$ MENEZES, Mauricio Moreira Mendonça de. Reflexões sobre o regime jurídico da coligação societária e a transferência de tecnologia entre sociedades coligadas. 2006. P. 9.

${ }^{34}$ ALMEIDA, Marcelo Cavalcanti. Auditoria. São Paulo: Atlas. p. 255.
} 


\subsection{Investimentos Relevantes e conceitos da legislação fiscal}

Para fins fiscais, a IN RFB $\mathrm{n}^{\mathbf{0}} 1.397 / 2013$ trouxe conceitos similares ao art. 243 da Lei das S.A. quando determina quais investimentos serão avaliados pelo método de equivalência patrimonial (o qual veremos no próximo capítulo):

“Art. 15. Serão avaliados pelo valor de patrimônio líquido, conforme o art. 248 da Lei $n^{\circ}$ 6.404, de 1976, vigente em 31 de dezembro de 2007, os investimentos relevantes da pessoa jurídica:

I - em sociedades controladas; e

II - em sociedades coligadas sobre cuja administração tenha influência, ou de que participe com $20 \%$ (vinte por cento) ou mais do capital social.

$\S 1^{\circ}$ São coligadas as sociedades quando uma participa, com $10 \%$ (dez por cento) ou mais, do capital da outra, sem controlá-la.

$\S 2^{\circ}$ Considera-se controlada a sociedade na qual a controladora, diretamente ou por meio de outras controladas, é titular de direitos de sócio que the assegurem, de modo permanente, preponderância nas deliberações sociais e o poder de eleger a maioria dos administradores."

Com relação aos investimentos a serem avaliados pelo método, temos no $\S 3^{\circ}$ do mesmo dispositivo a definição de "Investimentos Relevantes":

"I - em cada sociedade coligada ou controlada, se o valor contábil é igual ou superior a $10 \%$ (dez por cento) do valor do patrimônio líquido da pessoa jurídica investidora; ou

II - no conjunto das sociedades coligadas e controladas, se o valor contábil é igual ou superior a $15 \%$ (quinze por cento) do valor do patrimônio líquido da pessoa jurídica investidora." 


\section{CAPÍTULO IV - Do Método de Equivalência Patrimonial}

\subsection{Aspectos Contábeis}

Instituído pela Lei $\mathrm{n}^{\mathrm{o}}$ 6.404/7635, o método de equivalência patrimonial tem como objetivo a avaliação de um investimento de uma Sociedade na investida.

O valor do investimento em coligadas ou controladas no exterior será determinado mediante a aplicação do percentual da Sociedade investidoras no capital social das sociedades investidas sobre o valor do patrimônio líquido destas ${ }^{36}$.

ANDRADE FILHO conceitua o referido sistema de avaliação de investimentos:

"A sistemática legal de avaliação de investimentos pelo chamado "método de equivalência patrimonial" tem por função permitir que os resultados de uma sociedade que seja sócia ou acionista de outra reflitam, em cada balanço, o valor de participação nos lucros, prejuízos, ou qualquer outro acréscimo ou decréscimo ao patrimônio líquido das sociedades investidas." ${ }^{, 37}$

O pronunciamento técnico $\mathrm{n}^{\mathrm{o}} 19$ do CPC - Comitê de Pronunciamentos Contábeis, em seu item 3, define assim o método de equivalência patrimonial:

"Método de equivalência patrimonial é o método de contabilização por meio do qual o investimento é inicialmente reconhecido pelo custo e posteriormente ajustado pelo reconhecimento da participação atribuída ao investidor nas alterações dos ativos líquidos da investida. $\mathrm{O}$ resultado do período do investidor deve incluir a parte que lhe cabe nos resultados gerados pela investida."

Conforme supracitado, primeiramente o investimento em coligadas e controladas é reconhecido no ativo da Sociedade investidora pelo seu custo

\footnotetext{
${ }^{35}$ Artigo 248 caput, Lei $\mathrm{n}^{\mathrm{o}} 6.404 / 76$.

${ }^{36}$ Artigo 248, II, Lei $n^{\circ} 6.404 / 76$.

${ }^{37}$ ANDRADE F, Edmar Oliveira. Imposto de Renda das Empresas. São Paulo: Atlas, 2013, p. 632.
} 
de aquisição (valor contábil do investimento). Posteriormente, para atendimento à legislação comercial brasileira e às normas contábeis vigentes, a Sociedade investidora deve registrar como resultado do exercício os resultados de equivalência patrimonial, calculados com base na diferença entre o valor do investimento (percentual do capital sociedade na investida sobre o patrimônio líquido) e o custo de aquisição do investimento, corrigido monetariamente ${ }^{38}$

Como contrapartida do valor registrado a título de resultado de equivalência patrimonial, a Sociedade Investidora deverá registrar no seu ativo o acréscimo no montante investido, demonstrando a valorização de sua participação societária na sociedade controlada ou coligada.

\section{Contabilização com base no método de equivalência patrimonial}

1. A Sociedade "X" possui o seguinte balanço patrimonial.

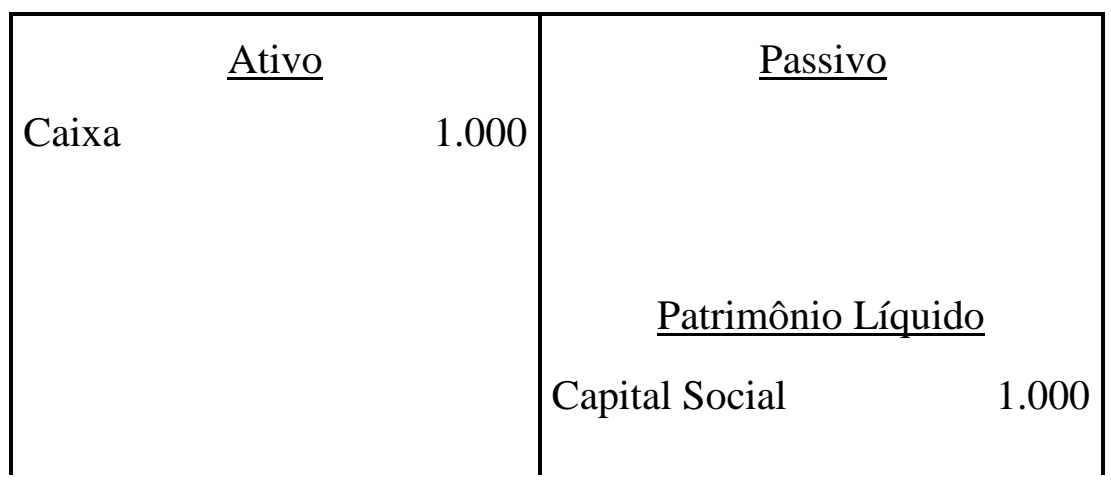

2. A Sociedade "X" adquiriu em 31 de dezembro de $2010,60 \%$ do capital social da Sociedade "Y" no valor de R\$100,00.

3. Neste momento, a Sociedade "X" registrará em seu Ativo o valor contábil do investimento.

${ }^{38}$ Artigo 248, III, Lei n ${ }^{\circ} 6.404 / 76$. 
Débito: Investimento na Sociedade "Y" - R\$ 100,00.

Crédito: Caixa - R\$ 100,00.

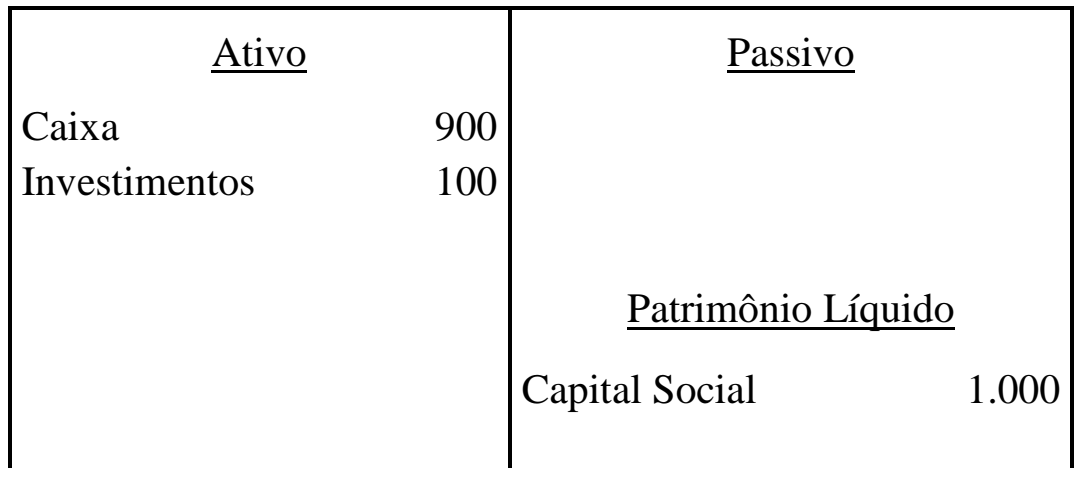

4. Em 2011, a Sociedade "Y" incorre em um lucro líquido de R\$ 20,00, não distribuído. O patrimônio líquido da Sociedade "Y", então, aumenta em R\$ 20,00 .

5. Com base no método de equivalência patrimonial, a Sociedade " $\mathrm{X}$ " deve registrar em seu balanço patrimonial o ajuste da seguinte forma:

Débito: Investimento na Sociedade "Y" - R\$ 12,00 (60\% x $\mathrm{R} \$ 20,00)$.

Crédito: Receita de equivalência patrimonial - R \$ 12,00.

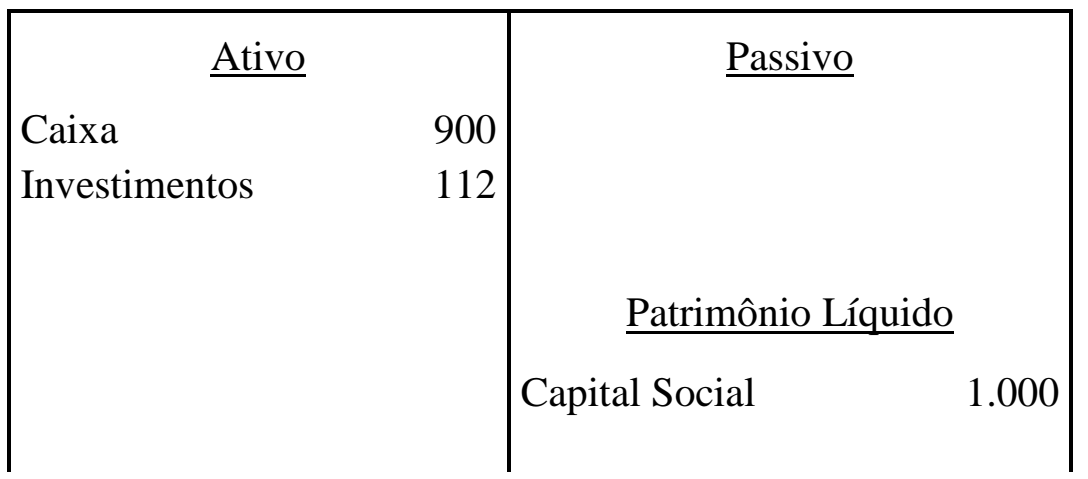

$\underline{\text { Demonstração do Resultado do Exercício }}$

Receita de Equivalência Patrimonial

6. Imaginemos, então, que o lucro da Sociedade "Y" tenha sido distribuído. Não teríamos, neste caso, um ajuste no resultado da investidora. 
Débito: Caixa - R \$ 12,00 (60\% x R \$ 20,00).

Crédito: Investimentos (Dividendos Recebidos "Y") - R \$

$12,00(60 \% \times \mathrm{R} \$ 20,00)$.

\begin{tabular}{|c|c|c|c|}
\hline \multicolumn{2}{|c|}{$\underline{\text { Ativo }}$} & \multicolumn{2}{|c|}{$\underline{\text { Passivo }}$} \\
\hline Caixa & 912 & \multirow{3}{*}{\multicolumn{2}{|c|}{$\underline{\text { Patrimônio Líquido }}$}} \\
\hline \multirow[t]{3}{*}{ Investimentos } & 100 & & \\
\hline & & & \\
\hline & & Capital Social & 1.000 \\
\hline
\end{tabular}

Demonstração do Resultado do Exercício

Receita de Equivalência Patrimonial

2

\subsection{Aspectos Tributários}

Para fins tributários, conforme fixado no art. 384 do RIR/99, devem ser avaliados pelo método de equivalência patrimonial os investimentos relevantes da pessoa jurídica em sociedades controladas e coligadas. Neste último caso, a legislação tributária restringe as sociedades coligadas àquelas sobre cuja administração tenha influência, ou de que a investidora participe com $20 \%$ ou mais do capital social.

O Parecer Normativo CST n ${ }^{\circ}$ 78/78 trouxe outra condição para que as investidoras adotarem o método: a relevância e a influência da investidora sobre a coligada ou controlada.

"2. De acordo com a Lei das Sociedades Anônimas (Lei n” 6.404/76, art. 247, Parágrafo único) um investimento em sociedade coligada ou controlada é relevante quando seu valor contábil é igual ou superior a $10 \%$ do valor do patrimônio líquido da sociedade anônima investidora. Também o é, mesmo sem atingir os $10 \%$, se o valor da participação, somado ao das demais participações em coligadas ou controladas, alcança pelo menos $15 \%$ do valor do patrimônio líquido da investidora. Investimentos em sociedades não coligadas nem controladas, não são considerados relevantes, não importa quão importantes sejam para a empresa investidora." 
$\mathrm{O}$ art. 389 do RIR/99 determina que o resultado positivo da equivalência patrimonial não será computado na determinação do lucro real. No entanto, com o advento do art. $7^{\circ}$ da Instrução Normativa SRF $n^{\circ} 213 / 2002$, os valores relativos ao resultado positivo da equivalência patrimonial em investimentos em coligadas ou controladas no exterior devem ser considerados na determinação do lucro real e da base de cálculo da CSLL.

“Art. $7^{\circ}$ A contrapartida do ajuste do valor do investimento no exterior em filial, sucursal, controlada ou coligada, avaliado pelo método da equivalência patrimonial, conforme estabelece a legislação comercial e fiscal brasileira, deverá ser registrada para apuração do lucro contábil da pessoa jurídica no Brasil.

$\S 1^{\circ}$ Os valores relativos ao resultado positivo da equivalência patrimonial, não tributados no transcorrer do ano-calendário, deverão ser considerados no balanço levantado em 31 de dezembro do ano-calendário para fins de determinação do lucro real e da base de cálculo da CSLL."

ANDRADE FILHO observa a determinação legal advinda da IN 213/2002 acerca da tributação dos resultados positivos da equivalência patrimonial:

"O mandamento final (...) determina que o resultado positivo da equivalência patrimonial seja tributado pela investidora, no Brasil, quando o ajuste decorrer de investimento em coligada ou controlada no exterior ou quando se referir a qualquer espécie de dependência no exterior cujos resultados sejam refletidos segundo as regras reitoras do método de equivalência patrimonial." 39

${ }^{39}$ ANDRADE F, Edmar Oliveira. Imposto de Renda das Empresas. São Paulo: Atlas, 2013, p. 523. 


\section{CAPÍTULO V - Outros Aspectos}

A seguir, serão abordados brevemente outros aspectos intrínsecos à incidência e cálculo do Imposto de Renda devido sobre lucros obtidos por controladas e coligadas no exterior.

\subsection{Investimentos Indiretos}

$\mathrm{O}$ art. 15 da IN RFB $\mathrm{n}^{\circ} 1.397 / 2013$, conforme mencionado no capítulo III deste trabalho, conceitua controladas como sociedades na qual a controladora, diretamente ou por meio de outras controladas, é titular de direitos de sócio que lhe assegurem, de modo permanente, preponderância nas deliberações sociais e o poder de eleger a maioria dos administradores.

Desta forma, o conceito abarca tanto as controladas diretas como os investimentos destas controladas estrangeiras em outras controladas também no exterior.

No que tange a tributação dos lucros obtidos no exterior, o $\S 6^{\circ}$ do art. $1^{\circ}$ da IN SRF $n^{\circ}$ 213/2002 determina que o alcance da incidência do Imposto de Renda também abrange investimentos indiretos no exterior:

" $\S 6^{\circ}$ Os resultados auferidos por intermédio de outra pessoa jurídica, na qual a filial, sucursal, controlada ou coligada, no exterior, mantenha qualquer tipo de participação societária, ainda que indiretamente, serão consolidados no balanço da filial, sucursal, controlada ou coligada para efeito de determinação do lucro real e da base de cálculo da CSLL da beneficiária no Brasil."

Ao examinar o caso da EAGLE DISTRIBUIDORA DE BEBIDAS S.A., a $1^{\text {a }}$ Câmara do Primeiro Conselho de Contribuintes (atual CARF) teve seu entendimento majoritário também no sentido de que os resultados 
obtidos por controladas indiretas no exterior consideram-se auferidos diretamente pela sociedade investidora no Brasil.

A sociedade investidora, no caso, era controladora de uma sociedade na Espanha que, por sua vez, controlava outras sociedades localizadas na Argentina e Uruguai.

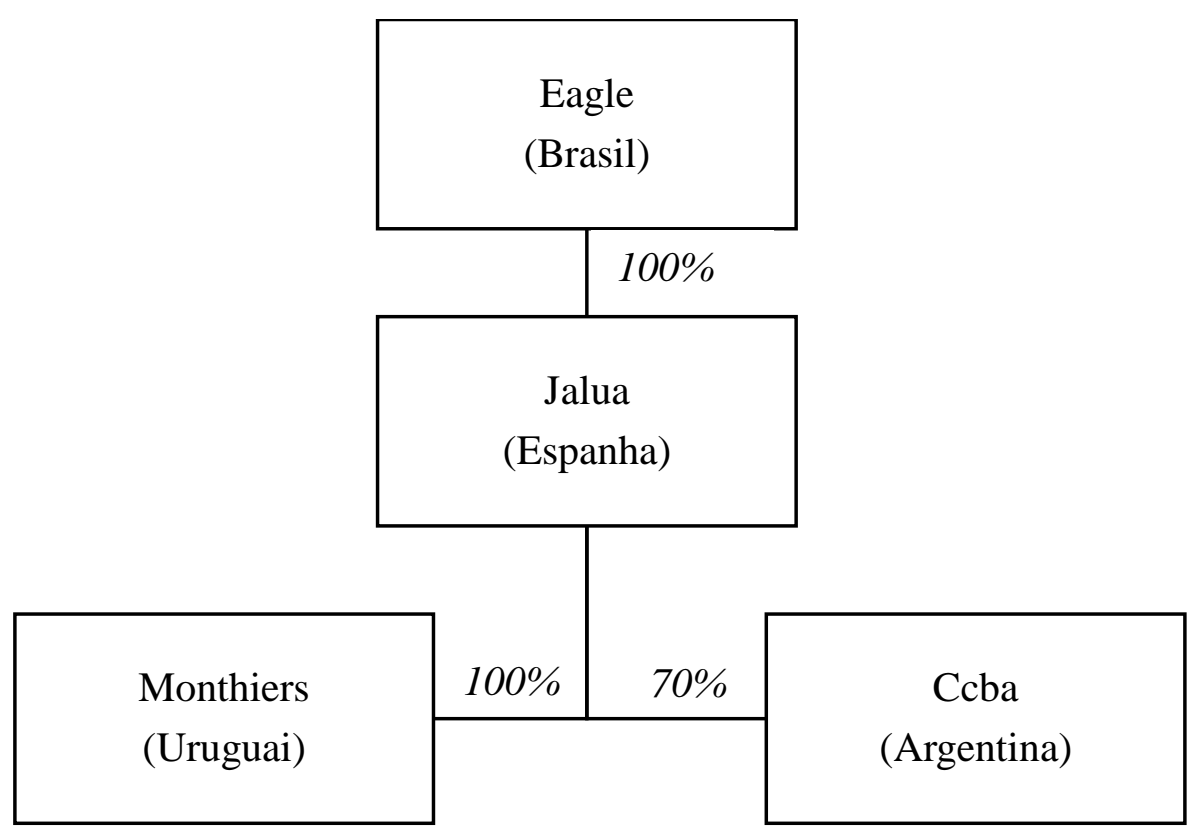

Por maioria dos votos, a Câmara decidiu que a legislação brasileira alcança os lucros obtidos por sociedades controladas indiretas no exterior.

"LUCROS AUFERIDOS NO EXTERIOR POR INTERMÉDIO DE CONTROLADAS INDIRETAS- Para fins de aplicação do art. 74 da MP $\mathrm{n}^{\circ}$ 2.158-35, os resultados de controladas indiretas consideram-se auferidos diretamente pela investidora brasileira, e sua tributação no Brasil não se submete às regras do tratado internacional firmado com o país de residência da controlada direta, mormente quando esses resultados não foram produzidos em operações realizadas no país de residência da controlada, evidenciando o planejamento fiscal para não tributá-los no Brasil."

A respeito da decisão, ANDRADE FILHO comenta:

"Prevaleceu a tese de que o poder de controle societário pode ser exercido de modo direto e indireto e, com base nele, é razoável supor que o seu detentor é titular de um direito de "propriedade" sobre os lucros das sociedades investidas independentemente de deliberação societária. A rigor, aceitou-se como válida a mal disfarçada "desconsideração da personalidade jurídica" em cascata na medida em que admite válida a 
tributação de lucro não disponibilizado por controlada direta e vai além ao considerar legítima a incidência sobre lucro de uma terceira sociedade, a denominada controlada indireta." ${ }^{40}$

De acordo com opinião de TÔRRES, a IN SRF 213/2002, "ao versar sobre lucros de controladas ou coligadas, não autoriza tributar "controladas indiretas", e nem poderia, por absoluta falta de competência tributária e inconteste ilegalidade. Ao contrário, o que faz a citada Instrução Normativa ${ }^{41}$ é vedar a consolidação de investimentos (i), mediante regra que obriga a individualização das empresas participadas, a exigir a demonstração financeira segundo as leis de destino (o que exclui a aplicação do art. 74 da MP nº 2158/2001) na apuração do lucro (ii) e que qualquer participação em outras sociedades, ainda que indiretamente, deverão ser consolidados no balanço da controlada ou coligada, mas sempre segundo as leis locais, e nunca segundo as leis brasileiras".

Conclui ainda que:

"Conclusão insuperável é a de que o art. 74 da Medida Provisória $\mathrm{n}^{0}$ 2.158/01 não alcança situações nas quais persista apenas vínculo indireto entre as pessoas jurídicas, em face dos limites assinalados acima e do princípio da separação patrimonial das sociedades, mormente quando entre ambas persistem soberanias fiscais diversas. Admitir-se a incidência de imposto de renda brasileiro sobre lucros auferidos na Argentina, por exemplo, cujos dividendos pertencem a beneficiário residente na Espanha, é situação absolutamente estranha ao direito positivo brasileiro, assim como a qualquer ordenamento jurídico, aqui ou alhures. Não é por menos que a segurança jurídica tributária, a cada passo, mais claudica do que se impõe como fator de estímulo para o crescimento econômico e as boas relações de negociais."

${ }^{40}$ ANDRADE F, Edmar Oliveira. Imposto de Renda das Empresas. São Paulo: Atlas, 2013, p. 518.

${ }^{41}$ TÔRRES, Heleno Taveira. Tributação de controladas e coligadas no exterior. São Paulo:

Fiscosoft, 2012. 


\subsection{Cálculo e Compensação do Imposto de Renda Devido no Brasil}

O Imposto de Renda devidos sobre lucros auferidos por coligadas ou controladas no exterior são calculados em conjunto com o imposto devido pela pessoa jurídica no Brasil.

De acordo com o arts. 13 e 14 da IN SRF no 213/2002, o Imposto de Renda pago no exterior sobre os lucros obtidos pelas coligadas e controladas da sociedade brasileira poderá ser compensado no Brasil.

Como observa HIGUCHI ${ }^{42}$, a compensação do imposto pago pela sociedade investida no exterior será proporcional aos lucros computados na determinação do lucro real.

Para efeitos de compensação, o imposto pago no exterior será convertido em Reais com base na taxa de câmbio da moeda do país de origem fixada pelo Banco Central do Brasil referente à data do efetivo pagamento.

Com relação à compensação do tributo pago no exterior, HIGUCHI faz a observação acerca de seus limites.

"O valor do imposto pago no exterior, a ser compensado, não poderá exceder o montante do imposto de renda e adicional devidos, no Brasil, sobre o valor dos lucros (...) auferidos no exterior, já era positivo, basta fazer dois cálculos do imposto devido na declaração, um antes da adição e outro depois da adição dos lucros. A diferença entre os dois cálculos é o limite para compensação do imposto pago no exterior. Se o imposto pago no exterior for menor que a diferença, o pagamento é obrigatório. Se o imposto no exterior for maior que a diferença, o excedente não poderá ser compensado com IRPJ."

\footnotetext{
${ }^{42}$ HIGUCHI, Hiromi. Imposto de Renda das Empresas: Interpretação Prática. São Paulo: IR Publicações, 2013. p. 142.

${ }^{43}$ HIGUCHI, Hiromi. Imposto de Renda das Empresas: Interpretação Prática. São Paulo: IR Publicações, 2013. p. 143. Art. 14, § 10 da IN SRF nº 213/2002.
} 
Cabe ressaltar que o tributo pago sobre lucros obtidos no exterior, que não puder ser compensado em virtude de a pessoa jurídica, no Brasil, no respectivo ano-calendário, não ter apurado lucro real positivo, poderá ser compensado com o que for devido nos anos-calendário subsequentes. ${ }^{44}$

Por fim, o art. 15 da IN SRF no 213/2002 determina que o valor do imposto pago no exterior também poderá ser aproveitado para a compensação da CSLL.

${ }^{44}$ Art. $14, \S 15$ da IN SRF no $213 / 2002$. 


\section{CAPÍTULO VI - Jurisprudência e Crítica Doutrinária}

Neste capítulo, apresentar-se-ão posições doutrinárias acerca da tributação dos lucros obtidos no exterior, assim como acórdãos administrativos e judiciais a respeito.

\subsection{Separação Patrimonial Entre Pessoas Jurídicas}

A partir da edição da MP 2.158-34 e seu art. 74, foi atribuída a obrigatoriedade às sociedades investidoras à tributação dos lucros obtidos no exterior por meio de suas coligadas e controladas, independentemente da distribuição destes lucros.

Neste momento, de acordo com ANDRADE FILHO, houve a "desconsideração da personalidade jurídica da sociedade investida" Explica o autor que a separação patrimonial não impede que os acionistas tracem os caminhos e definam planos de ação para a sociedade investida. No entanto, destaca que "não podem dispor livremente dos bens da sociedade ainda que possam ser considerados os senhores da sua existência e de sua extinção, na forma como dispuserem as normas em vigor em cada comunidade",46.

A posição majoritária da doutrina é contra a previsão legal relativa ao art. 74, consistindo na alegação de que se estaria tributando renda alheia, representando "uma desconsideração da personalidade jurídica da empresa estrangeira, a qual não encontraria guarida no ordenamento pátrio",47 .

Conforme entendimento de COELHO, a separação do patrimônio da pessoa jurídica e de seus sócios, além de trazer maior segurança jurídica, possibilita o crescimento econômico das sociedades empresárias.

\footnotetext{
45 ANDRADE F, Edmar Oliveira. Imposto de Renda das Empresas. São Paulo: Atlas, 2013, p. 508.

${ }^{46}$ Idem.

${ }^{47}$ GRECO, Marco Aurélio; ROCHA, Sergio André. Manual de Direito Tributário Internacional. São Paulo: Dialética, 2012, p. 393.
} 
"Se não existisse o princípio da separação patrimonial, os insucessos da exploração da empresa poderiam significar a perda de todos os bens particulares dos sócios, amealhados ao longo do trabalho de uma vida ou mesmo de gerações, e, nesse quadro, menos pessoas se sentiriam estimuladas a desenvolver novas atividades empresariais." 48

O conceito de separação patrimonial encontra-se fixado no art. 1.024 de nosso Código Civil de 2002, cuja determinação é de que os "bens particulares dos sócios não podem ser executados por dívidas da sociedade, senão depois de executados os bens sociais".

Por outro lado, o nosso código civil traz a possibilidade de desconsideração da personalidade jurídica em face de atos ilícitos praticados pela sociedade:

"Art. 50. Em caso de abuso da personalidade jurídica, caracterizado pelo
desvio de finalidade, ou pela confusão patrimonial, pode o juiz decidir, a
requerimento da parte, ou do Ministério Público quando lhe couber
intervir no processo, que os efeitos de certas e determinadas relações de
obrigações sejam estendidos aos bens particulares dos administradores ou
sócios da pessoa jurídica."

Desta forma, resta claro que as pessoas jurídicas possuem patrimônio incomunicável com seus sócios, além da capacidade de praticar atos jurídicos próprios. No entanto, a personalização nunca será absoluta, já que a figura da autonomia patrimonial pode ser utilizada para a prática de atos fraudulentos ou abusos de direito.

Neste ponto, imaginemos uma Sociedade brasileira que seja controladora de outra sociedade localizada na Espanha. A sociedade investidora no Brasil possui controle sobre a sociedade espanhola, o que significa dizer que possui a capacidade de estabelecer metas, normas administrativas visando o bom desempenho da controlada. No entanto, não é a sociedade investidora detentora absoluta dos bens da sociedade controlada. Esta possui obrigações para com seus credores, clientes, funcionários, além de eventuais outros acionistas.

\footnotetext{
${ }^{48}$ COELHO, Fábio Ulhoa. Curso de Direito Comercial. 13. ed. São Paulo: Saraiva, 2009. p. 16.
}

${ }^{49}$ Art. 50 da Lei n ${ }^{\circ}$ 10.406/2002. 
Ao encerrar o fechamento de suas demonstrações contábeis, a sociedade espanhola (na figura de seu controlador e outros acionistas) decide por não distribuir seus lucros na forma de dividendos. Ao invés, a sociedade espanhola optou por reinvestir os lucros auferidos no período em novos projetos industriais em território espanhol.

Eis que a legislação tributária e as autoridade fiscais brasileiras, com fundamento no art. 74 da MP 2.158-35/2001, exigem o pagamento do Imposto de Renda sobre os lucros obtidos no exterior, mesmo que não tenham estes sido distribuídos.

Não estando os lucros da controlada à disposição da sociedade investidora, indaga-se se não estaria a administração tributária levantando o véu da pessoa jurídica espanhola, exigindo-lhe a apresentação de suas informações contábeis e posterior recolhimento de tributo sobre montante não disponibilizado, sem que estivesse a sociedade brasileira praticando nenhuma ilicitude ou conduta abusiva ${ }^{50}$.

Para ANDRADE FILHO, parece "razoável que a legislação tributária não pode transpor o limite imanente da separação patrimonial que é uma decorrência natural da aquisição personalidade jurídica pela sociedade investida no exterior, mormente nos casos em uma lei complementar diz que a tributação deve recair sobre a disponibilidade do lucro" $"$.

TÔRRES vai além ao mencionar outros princípios violados pela norma tributária:

"Não reconhecer a força vinculante dos tipos societários, no caso, daqueles que garantem a separação patrimonial, é conferir privilégio à Administração Tributário em conflito com a Constituição e os valores do

\footnotetext{
${ }^{50}$ XAVIER, Alberto. A tributação dos lucros de controladas e coligadas de empresas brasileiras no exterior e os tratados contra a dupla tributação. In: Revista Tributária e de Finanças Públicas, $\mathrm{n}^{\mathrm{o}}$ 3, ano 3. Almedina, 2010, p. 19.

51 ANDRADE F, Edmar Oliveira. Imposto de Renda das Empresas. São Paulo: Atlas, 2013, p. 512.
} 
direito de propriedade e da livre iniciativa. É dar ao Fisco uma carta em branco para desconsiderar, sem qualquer limite, os tipos societários." ${ }^{, 52}$

\subsection{Violação do Conceito Constitucional de Renda}

A CRFB, em seu art. 153, III, estabeleceu a competência da União para instituir imposto sobre a renda e proventos de qualquer natureza.

O fato gerador do Imposto de Renda é determinado no art. 43 do CTN:
"Art. 43. O imposto, de competência da União, sobre a renda e proventos de qualquer natureza tem como fato gerador a aquisição da disponibilidade econômica ou jurídica:
I - de renda, assim entendido o produto do capital, do trabalho ou da combinação de ambos;
II - de proventos de qualquer natureza, assim entendidos os acréscimos patrimoniais não compreendidos no inciso anterior."

Com relação ao aspecto material, temos que o núcleo do fato gerador do Imposto de Renda é o acréscimo patrimonial realizado. GONÇALVES leciona acerca da condição material extraída da CRFB:

"A Constituição somente admite a incidência de imposto sobre a renda quando tenha havido alteração positiva no patrimônio do contribuinte, no período. Fora daí, não se admite (...) incidência do imposto sobre a renda." $" 53$

A questão temporal, ocasião na qual se considera concretizado o fato gerador do tributo, portanto, estaria condicionada à materialização do acréscimo patrimonial, conforme observado pelo mestre ANDRADE FILHO:

"A noção de acréscimo patrimonial, de certo modo, estabelece os limites ao poder de configuração do legislador que não pode construir hipótese

\footnotetext{
${ }^{52}$ TÔRRES, Heleno Taveira. Tributação de controladas e coligadas no exterior. São Paulo: Fiscosoft, 2012.

${ }^{53}$ GONÇALVES, José Artur L. Imposto sobre a renda: pressupostos constitucionais. São Paulo: Malheiros, 1997, p. 198.
} 
de incidência que não representa, a partir de um juízo de racionalidade e razoabilidade, a ideia de acréscimo ocorrido num dado lapso temporal." ${ }^{, 54}$

A Lei Complementar $n^{\circ}$ 204/2001 trouxe mudanças ao art. 43 do $\mathrm{CTN}$, acrescentando-lhe o parágrafo $2^{\circ}$ no qual se prescreve que, caso a receita ou rendimento sejam oriundos do exterior, "a lei estabelecerá as condições e o momento em que se dará sua disponibilidade" para fins de incidência do Imposto de Renda.

Note que o critério material do Imposto de Renda não foi alterado pela Lei Complementar, sendo mantido, portanto, o acréscimo patrimonial disponível o fato gerador do tributo. Quanto à disponibilidade, pode-se considerar como acréscimo patrimonial disponível quando o contribuinte do Imposto de Renda (no caso a sociedade investidora brasileira) passa a dispor dos lucros distribuídos pela controlada ou coligada no exterior. Este momento, em consonância com o art. 132 da Lei no 6.404/76, somente se dá após a deliberação da assembleia-geral neste sentido.

Neste sentido, não sendo decidida a distribuição dos lucros pela assembleia-geral da sociedade controlada ou coligada (conforme estipulado pela legislação societária do país no qual está sediada), "não caberia a incidência da regra que determina o nascimento de uma obrigação tributária relativa ao Imposto de Renda, sob pena de ofensa ao sentido e alcance do texto constitucional ${ }^{, 55}$.

Marco Aurélio Greco, analisando o ordenamento jurídico brasileiro, possui visão contrária acerca do tema. Para ele, identificando-se um acréscimo patrimonial na empresa brasileira, de modo a caracterizar a existência de proventos de qualquer natureza, o art. 74 da MP 2.158/2001 estaria perfeitamente em linha com o texto da Carta Magna ${ }^{56}$.

\footnotetext{
${ }^{54}$ ANDRADE F, Edmar Oliveira. Imposto de Renda das Empresas. São Paulo: Atlas, 2013, p. 25.

${ }^{55}$ ANDRADE F, Edmar Oliveira. Imposto de Renda das Empresas. São Paulo: Atlas, 2013, p. 504.

${ }_{56}^{5}$ GRECO, Marco Aurélio; ROCHA, Sergio André. Manual de Direito Tributário Internacional. São Paulo: Dialética, 2012, p. 395.
} 
O comentário de GRECO é no sentido de se avaliar o aumento do patrimônio da sociedade brasileira em virtude da obtenção e lucros no exterior por parte da sociedade controlada ou coligada, mesmo que estes lucros não sejam distribuídos.

“(...) uma avaliação do patrimônio da (empresa) brasileira no dia seguinte à data do balanço da (empresa) estrangeira que tiver apurado seus lucros, certamente (em função dessa participação societária) apontará um valor maior do que ela teria na véspera do seu conhecimento no balanço da estrangeira. A rigor, a participação societária titularizada pela brasileira passa a valer mais por existirem lucros reconhecidos no balanço da controlada ou coligada, ainda que não distribuídos." ${ }^{, 57}$

É com base neste argumento que o CARF vêm decidindo pela inclusão do resultado da equivalência patrimonial na determinação do lucro real, já que este resultado, quando positivo, atesta a apuração dos lucros pela coligada ou controlada ${ }^{58}$.

"IRPJ - EQUIVALÊNCIA PATRIMONIAL - INVESTIMENTOS NO EXTERIOR - Os resultados positivos da avaliação dos investimentos pelo método de equivalência patrimonial, segundo a legislação do Imposto de Renda, não se enquadram na categoria de lucros auferidos pela controladora sujeitos à incidência desse Imposto. Entretanto, com o comando fixado pelo artigo 74 da Medida Provisória n. 2.158-35/2001, o resultado positivo dessa equivalência decorrente de investimentos no exterior, integram a base de cálculo do lucro real e da CSLL."

No entanto, deve-se observar que, como já visto neste trabalho, a equivalência patrimonial somente evidencia a avaliação dos investimentos feitos por um sociedade em outra. A variação positiva somente se concretiza em acréscimos patrimoniais disponíveis para a sociedade investidora no momento da liquidação deste investimento.

Assim, o art. 74 da MP 2.158/2001 combinado com o texto da IN $\mathrm{n}^{\mathrm{o}}$ 213/2002, quando dos lucros não distribuídos pela sociedade controlada ou

\footnotetext{
${ }^{57}$ GRECO, Marco Aurélio; ROCHA, Sergio André. Manual de Direito Tributário Internacional. São Paulo: Dialética, 2012, p. 396.

${ }^{58}$ Voto de Valmir Sandri, quando da relatoria do Recurso Voluntário $n^{\circ}$ 153.731. Primeiro

Conselho de Contribuintes, Primeira Câmara.
} 
coligada, estaria determinando uma disponibilização automática dos resultados positivos de equivalência patrimonial ${ }^{59}$.

Neste sentido, ROCHA comenta:

“(...) a injustiça da tributação pretendida pelo artigo 74 da Medida Provisória $\mathrm{n}^{\mathrm{o}} 2.158-35 / 2002$ fica ainda mais evidente na medida em que se pretendeu, através da Instrução Normativa $n^{\circ}$ 213/2002, tributar os efeitos positivos da equivalência patrimonial do investimento estrangeiro sem, contudo autorizar-se a dedução dos efeitos negativos da mesma equivalência patrimonial. Se a receita de equivalência patrimonial deveria ser tratada como um acréscimo patrimonial tributável, o mínimo que a legislação deveria prever é a dedutibilidade da despesa de equivalência patrimonial, que deveria ser tratada como um decréscimo patrimonial.".60

Adicionalmente, como se trata de uma variação patrimonial da sociedade investida, os resultados positivos de equivalência patrimonial não necessariamente representam a obtenção de lucros por parte da empresa estrangeira.

A constitucionalidade do art. 74 da MP 2.158/2001 está atualmente sendo discutida no Supremo Tribunal Federal na Ação Direta de Inconstitucionalidade $\mathrm{n}^{\mathrm{o}}$ 2.588. A ADI, proposta pela Confederação Nacional da Indústria (CNI) alega a violação do art. 74 ao artigo 153, III da CRFB.

A relatora Ministra Ellen Gracie votou pela inconstitucionalidade do dispositivo no que tange às coligadas. $\mathrm{O}$ argumento utilizado pela ministra foi o de que as coligadas não teriam o controle sobre a decisão de distribuir os lucros obtidos no exterior.

O voto do Ministro Nelson Jobim, acompanhado pelo Ministro Eros Grau, foi no sentido de improcedência integral da ADI, já que, segundo o ministro, o resultado positivo de equivalência patrimonial geraria a disponibilidade de renda para a sociedade investidora brasileira (fato gerador do Imposto de Renda).

\footnotetext{
${ }^{59}$ GRECO, Marco Aurélio; ROCHA, Sergio André. Manual de Direito Tributário Internacional. São Paulo: Dialética, 2012, p. 396.

${ }^{60}$ GRECO, Marco Aurélio; ROCHA, Sergio André. Manual de Direito Tributário Internacional. São Paulo: Dialética, 2012, p. 397.
} 
O Ministro Marco Aurélio, acompanhado pelos Ministros Ricardo Lewandowski e Sepúlveda Pertence, votou pela procedência da ação. Os ministros entenderam que os resultados da sociedade investida estrangeira, quando não disponibilizados, não poderiam ser tributados.

Em seguida, o Ministro Ayres Britto julgou improcedente a ação. O ministro alegou que os resultados positivos das sociedades investidas estrangeiras gerariam acréscimos patrimoniais passíveis de tributação, plenamente em linha com o princípio de tributação universal adotado pelo Brasil.

Acompanhando os votos dos Ministros Marco Aurélio, Sepúlveda Pertence e Ricardo Lewandowski, o Ministro Celso de Mello reconheceu a procedência da ação, alegando a impossibilidade de se desconsiderar a personalidade jurídica da sociedade investida estrangeira.

O Ministro Cezar Peluso julgou improcedente a ação, fazendo a ressalva à metodologia de se obter o montante objeto da tributação no Brasil. Os resultados positivos de equivalência patrimonial serviriam de base para a tributação somente se reduzidos outras variações positivas que não os lucros obtidos.

O Ministro Joaquim Barbosa julgou parcialmente procedente a ADI para dar interpretação conforme a Constituição ao art. 74 da Medida Provisória $\mathrm{n}^{\circ} 2.158$, de modo a limitar a sua aplicação à tributação das pessoas jurídicas sediadas no Brasil cujas coligadas ou controladas no exterior estejam localizadas em países de tributação favorecida, ou seja, países desprovidos de controles societários e fiscais adequados, normalmente conhecidos como "paraísos fiscais".

Prosseguindo no julgamento, o Tribunal, por maioria, julgou parcialmente procedente a ação para, com eficácia erga omnes e efeito vinculante, conferir interpretação conforme, no sentido de que o art. 74 da MP n ${ }^{\circ} 2$.158-35/2001 não se aplica às empresas "coligadas" localizadas em países sem tributação favorecida (não "paraísos fiscais"), e que o referido 
dispositivo se aplica às empresas "controladas" localizadas em países de tributação favorecida ou desprovidos de controles societários e fiscais adequados ("paraísos fiscais", assim definidos em lei) ${ }^{61}$.

Posteriormente, considerando o julgamento da ADI 2.588, o STF aplicou o mesmo entendimento ao Recurso Extraordinário $\mathrm{n}^{\circ} 611.586$ impetrado pela Cooperativa Agropecuária Mourãoense Ltda. (COAMO). A cooperativa controlava sociedade localizada em Aruba, considerara paraíso fiscal. O STF autorizou a tributação dos lucros não distribuídos obtidos pela controlada da COAMO.

Já no que tange ao RE 541.090, o STF determinou que os autos fossem remetidos aos tribunais inferiores para discussão acerca do eventual conflito entre o art. 74 da MP 2.158 e os Tratados Internacionais para Evitar a Dupla Tributação. Isto porque, como veremos a seguir, a situação complexa não foi ainda apreciada pelo Supremo Tribunal Federal.

\subsection{A Compatibilidade do art. 74 da MP 2.158 com as Convenções Para Evitar a Dupla Tributação (CDT)}

Assunto deveras importante na aplicação das regras de transparência fiscal internacional é sua compatibilidade com as convenções para evitar a dupla tributação.

Acerca do eventual conflito entre as notas antielisivas brasileiras e os tratados tributários celebrados entre os países, João Francisco Bianco comenta que a Convenção Modelo da Organização para a Cooperação e Desenvolvimento Económico ou Econômico (OCDE) não seria aplicável ao modelo de transparência fiscal adotado pelo Brasil ${ }^{62}$.

A Convenção Modelo da OCDE, em seu artigo $7^{\circ}$, estabelece:

\footnotetext{
${ }^{61}<$ http://stf.jus.br/portal/peticaoInicial/verPeticaoInicial.asp?base $=$ ADIN\&s1 $=2588 \&$ processo $=25$ 88>. Acesso em: 01/10/2013.

${ }^{62}$ BIANCO, João Francisco. Transparência fiscal internacional. São Paulo: Dialética, 2007. p. 158.
} 
"Os lucros de uma empresa de um Estado contratante só podem ser tributados nesse Estado, a não ser que a empresa exerça a sua atividade no outro Estado contratante por meio de um estabelecimento permanente $^{63}$ aí situado. Se a empresa exercer a sua atividade deste modo, os seus lucros podem ser tributados no outro Estado, mas unicamente na medida em que forem imputáveis a esse estabelecimento permanente."

\section{Com relação à tributação dos dividendos, o artigo $10^{\circ}$ da referida} convenção diz o seguinte:

"1. Os dividendos pagos por uma sociedade residente de um Estado contratante a um residente do outro Estado contratante podem ser tributados nesse outro Estado.

2. Esses dividendos podem, no entanto, ser igualmente tributados no Estado contratante de que é residente a sociedade que paga os dividendos e de acordo com a legislação desse Estado, mas se o beneficiário efetivo dos dividendos for um residente do outro Estado contratante, o imposto assim estabelecido não excederá:

a) 5\% do montante bruto dos dividendos, se o seu beneficiário efetivo for uma sociedade (com exceção de uma sociedades de pessoas) que detenha, diretamente, pelo menos, $25 \%$ do capital da sociedade que paga os dividendos;

b) $15 \%$ do montante bruto dos dividendos, nos restantes casos."

\section{HIGUCHI faz uma síntese do exposto nos artigos supracitados:}

"Note-se (...) que a competência para cobrar o imposto de renda sobre os lucros das empresas é exclusivamente do país em que esteja situada a empresa. A tributação dos dividendos pagos (incluídos os lucros de outras formas societárias) será feita primeiramente pelo país da fonte pagadora, mas a alíquota do imposto não poderá ser superior à da convenção. O país recebedor do dividendo poderá cobrar o imposto sem limitação de alíquota, mas terá que deduzir o imposto cobrado no outro país." ${ }^{64}$

\section{O autor ainda assevera que o Brasil não poderia tributar integralmente o lucro apurado pela sociedade controlada ou coligada}

\footnotetext{
${ }^{63}$ XAVIER, Alberto. A tributação dos lucros de controladas e coligadas de empresas brasileiras no exterior e os tratados contra a dupla tributação. In: Revista Tributária e de Finanças Públicas, $n^{\circ} 3$, ano 3. Almedina, 2010, p. 22: "Estabelecimento permanente é, nos termos do art. $5 .^{\circ}, \S 1 .^{\circ}$, dos tratados (seguindo também o art. $5^{\circ}$ da Convenção Modelo da OCDE) "uma instalação fixa onde a empresa exerça toda ou parte da sua atividade", compreendendo notadamente um local de direção, uma sucursal, um escritório, uma fábrica, uma oficina, uma mina ou uma pedreira.

São, pois, "estabelecimentos permanentes", para efeito dos tratados, as sucursais ou filiais destituídas de personalidade jurídica própria."

${ }^{64}$ HIGUCHI, Hiromi. Imposto de Renda das Empresas: Interpretação Prática. São Paulo: IR

Publicações, 2013. p. 138.
} 
localizada em país com o qual tenha acordo para evitar a bitributação da renda:

\begin{abstract}
"Nenhuma empresa industrial, comercial, ou de determinado tipo de serviços, de qualquer país, tem possibilidade de distribuir a totalidade dos lucros apurados no balanço anual. Com isso, o valor do dividendo ou lucro distribuído é sempre menor que o montante do lucro apurado em balanço. O Brasil, ao tributar a totalidade do lucro apurado pela controlada ou coligada estabelecida no país que tem acordo para evitar a dupla tributação de renda, está desobedecendo à convenção." ${ }^{\circ 5}$
\end{abstract}

XAVIER leciona a respeito da incompatibilidade das normas antielisivas adotadas pelo Brasil com os artigos da Convenção:

"Não é demais insistir em que a cláusula de competência exclusiva do art. 7. dos tratados constitui o "coração" dos tratados contra a dupla tributação. Sem ela, qualquer tratado fica privado de sentido, pois abre as portas a uma guerra fiscal entre Estados, permitindo que a riqueza tributável em uma delas seja objeto de pretensões fiscais cumulativas de outras, invasivas de soberania estrangeira. É o que ocorreria se os Estados Unidos pudessem tributar naquele país os lucros das subsidiárias brasileiras, o Brasil pudesse tributar os lucros das suas controladas na Dinamarca, e até ad infinitum em todos os elos de uma cadeia vertical de controle.

A incompatibilidade com os tratados contra a dupla tributação decorre ainda de a sistemática por eles adotada apenas prever um mecanismo de eliminação da dupla tributação dos lucros distribuídos quando a tributação ocorre no momento da distribuição, tendo esta como fato gerador (...). Essa sistemática não prevê, porém, que a tributação ocorra em momento anterior ao da distribuição efetiva, quando ainda são lucros não distribuídos pela pessoa jurídica estrangeira, pelo que a dupla tributação neste caso não tem no tratado sistema de eliminação, que fica exclusivamente ao sabor da vontade das leis internas dos Estados em causa.”

A questão da compatibilidade do art. 74 da MP 2.158 com as convenções sobre a tributação de renda celebradas pelo Brasil não encontra entendimento pacificado nas decisões administrativas.

O $1^{\mathrm{o}}$ Conselho de Contribuintes (atual CARF), no julgamento do "Caso Eagle" (já tratado no capítulo anterior), decidiu que os lucros apurados pela sociedade controlada da Eagle na Espanha (Jalua) não

\footnotetext{
${ }^{65}$ HIGUCHI, Hiromi. Imposto de Renda das Empresas: Interpretação Prática. São Paulo: IR Publicações, 2013. p. 138.
} 
seriam suscetíveis à tributação no Brasil, pelo fato de a Espanha manter acordo de bitributação com o Brasil (promulgado pelo Decreto $\mathrm{n}^{\mathrm{o}}$ $76.975 / 76)$.

"LUCROS ORIUNDOS DE INVESTIMENTO NA ESPANHA - Nos termos da Convenção Destinada a Evitar a Dupla Tributação e Prevenir a Evasão Fiscal em Matéria de Imposto sobre a Renda entre Brasil e a Espanha, promulgada pelo Decreto ${ }^{\circ} 76.975$, de 1976, em se tratando de lucros apurados pela sociedade residente na Espanha e que não sejam atribuíveis a estabelecimento permanente situado no Brasil, não pode haver tributação no Brasil.,"66

Já no acórdão de $\mathrm{n}^{\circ}$ 140.200.391, o Conselho Administrativo de Recursos Fiscais (CARF) decidiu pela tributação de lucros auferidos por empresa controlada localizada na Hungria, por entender que a tributação não alcançaria lucros da empresa estrangeira, mas sim, lucros próprios da sociedade investidora brasileira.

“A Legislação Tributária Brasileira não estabelece incidência sobre os lucros da controlada estrangeira (o que é vedado pelo Artigo VII), mas sim sobre lucros da investidora brasileira, isto é, dispõe que o lucro real da contribuinte engloba os lucros disponibilizados por sua controlada, incorporados ao seu patrimônio em função do Método da equivalência Patrimonial MEP."

Hiromi Higuchi comenta acerca da decisão proferida pelo CARF. Na opinião do autor, ainda que a IN 213/2002 determine o cômputo dos resultados positivos de equivalência patrimonial no lucro real da sociedade investidora, não há previsão legal para este procedimento:

"A tributação foi mantida pelo voto de qualidade mas é absurda porque tributou a contrapartida da equivalência patrimonial, contrariando o disposto no $\S 6^{\circ}$ do art. 25 da Lei $n^{\circ} 9.249$ de 1995., ${ }^{, 67}$

Sérgio André Rocha também comenta acerca da incompatibilidade da legislação brasileira com as convenções tributárias celebradas pelo país:

“(...) de uma perspectiva de substância, o que se alcança com o artigo 74 da Medida Provisória n ${ }^{\circ}$ 2.158-35/2001 é efetivamente a tributação dos

\footnotetext{
${ }^{66}$ Primeiro Conselho de Contribuintes, Primeira Câmara, Acórdão n 101-97.070, Rel. Sandra Maria Faroni.

${ }^{67}$ HIGUCHI, Hiromi. Imposto de Renda das Empresas: Interpretação Prática. São Paulo: IR Publicações, 2013. p. 139.
} 
lucros da empresa não residente, como deixa claro a própria redação deste artigo, ao determinar que "os lucros auferidos por controlada ou coligada no exterior serão considerados disponibilizados para a controladora ou coligada no Brasil na data do balanço no qual tiverem sido apurados". Dessa forma, haveria aqui uma espécie de "planejamento tributário abusivo" do Estado brasileiro para se furtar ao cumprimento das obrigações assumidas nos tratados internacionais. Como está em voga no Direito Tributário brasileiro, neste caso não basta o exame da forma, sendo necessário examinar se a substância da tributação pretendida está em compasso com as convenções tributárias celebradas pelo Brasil, o que não parece ser o caso." ${ }^{, 68}$

No sentido contrário, a RFB, por meio da Solução de Consulta Interna $n^{\circ}$ 18/2013, admitiu a compatibilidade de aplicação do artigo 74 com o determinado nos acordos tributários internacionais celebrados pelo Brasil.

A referida solução de consulta alega que o art. 74 da MP 2.158 não gera conflito com as convenções tributárias, já que a tributação somente alcançaria os lucros obtidos por sociedades brasileiras e não sobre os lucros das sociedades investidas.

${ }^{68}$ GRECO, Marco Aurélio; ROCHA, Sergio André. Manual de Direito Tributário Internacional. São Paulo: Dialética, 2012, p. 409. 


\section{CAPÍTULO VII - Considerações Finais}

Ante o exposto no presente trabalho, verificamos que o Brasil, seguindo o movimento mundial de combate às práticas fiscais elisivas, adotou o princípio da tributação universal.

No entanto, o modelo adotado pelo Brasil se diferencia em diversos aspectos das regras de CFC seguidas por países como Estados Unidos, Reino Unido, Alemanha e França. Em princípio, estes países buscam tributar rendimentos específicos auferidos por sociedades não-residentes localizadas em países que oferecem tributação favorecida. Em suma, os instrumentos de transparência fiscal internacional são regimes excepcionais de combate a práticas de planejamento tributário abusivos.

Com o advento do art. 74 da MP 2.158/2001, o Brasil tributa indiscriminadamente os lucros obtidos no exterior por sociedades controladas e coligadas. Ademais, foi criado no ordenamento jurídico brasileiro um mecanismo de disponibilização automática de lucros, ou seja, presume-se que os rendimentos obtidos pela sociedade estrangeira são disponibilizados na data do balanço no qual tiverem sido apurados.

Após a edição da IN 213/2002, o legislador foi além. Determinou que a tributação do Imposto de Renda recairia sobre os resultados positivos de equivalência patrimonial, até então fora do campo de incidência do imposto.

Os resultados positivos de equivalência patrimonial, além de serem potencialmente incrementados por variações alheias à obtenção de lucros, representam variações apenas transitórias nos investimentos da sociedade investidora, quando os lucros não são distribuídos. Ademais, a separação patrimonial entre o patrimônio da sociedade investidora e investida deve ser observada. 
Até o presente momento, o posicionamento da jurisprudência administrativa vêm, majoritariamente, respeitando o fixado na legislação tributária brasileira.

Recentemente, o STF julgou ADI que alegava a violação do art. 74 da MP 2.158 ao conceito constitucional de renda. O Tribunal julgou que o referido dispositivo se aplica tão-somente às empresas "controladas" localizadas em países de tributação favorecida ou desprovidos de controles societários e fiscais adequados.

No entanto, o Supremo Tribunal Federal ainda não julgou a compatibilidade do art. 74 da MP 2.158/2001 com as Convenções Para Evitar a Dupla Tributação celebradas pelo Brasil. No que tange ao tema, resta claro que o Estado brasileiro não tem a pretensão de cumprir as obrigações por ele assumidas nos tratados quando tributa, indiscriminadamente, os lucros e resultados positivos apurados pela sociedade controlada ou coligada estrangeira.

Por fim, conclui-se que:

(1) as normas tributárias antielisivas adotadas pelo Brasil representam um sistema de "universalidade ampliada" de tributação extraterritorial. Este sistema apresenta importantes diferenças quando comparados a sistemas internacionais de transparência fiscal (CFC Rules);

(2) $\mathrm{o}$ art. 74 da Medida Provisória no 2.158-35/2001 veio determinar a tributação indiscriminada de lucros obtidos no exterior, mesmo que não distribuídos, violando o princípio constitucional de renda;

(3) o mesmo dispositivo legal fere a separação patrimonial entre a sociedade investidora brasileira e suas coligadas ou controladas no exterior, sem que haja prática abusiva ou fraude por parte das empresas; 
(4) a IN SRF 213/2002 não possui respaldo legal para a inclusão dos resultados de equivalência patrimonial na determinação do lucro real. Ademais, tais resultados representam tão-somente uma variação transitória do valor do investimento realizado por sociedades investidoras brasileiras;

(5) O STF julgou que o art. 74 da MP no 2 .158-35/2001 não se aplica às empresas "coligadas" localizadas em países sem tributação favorecida (não "paraísos fiscais"), e que o referido dispositivo se aplica às empresas "controladas” localizadas em países de tributação favorecida ou desprovidos de controles societários e fiscais adequados ("paraísos fiscais", assim definidos em lei);

(6) Contudo, o Supremo Tribunal Federal ainda não julgou a incompatibilidade do art. 74 com tratados tributários internacionais, claramente manifesta quando observada a tributação, por parte do Estado Brasileiro, de lucros obtidos em países com os quais mantem acordos que buscam coibir a dupla tributação da renda;

(7) Falta, portanto, aprimoramento no sistema de transparência fiscal brasileiro para que o imposto de renda incida somente em casos excepcionais de tentativa de evasão fiscal ou de planejamentos tributários abusivos. 


\section{BIBLIOGRAFIA}

ALMEIDA, Marcelo Cavalcanti. Auditoria. São Paulo: Atlas.

ANDRADE F, Edmar Oliveira. Imposto de Renda das Empresas. São Paulo: Atlas, 2013.

BIANCO, João Francisco. Transparência fiscal internacional. São Paulo: Dialética, 2007.

CARRAZA, Roque Antonio. Imposto sobre a Renda: perfil constitucional e temas específicos. São Paulo: Malheiros, 2005.

COELHO, Fábio Ulhoa. Curso de Direito Comercial. 13. ed. São Paulo: Saraiva, 2009.

GONÇALVES, José Artur L. Imposto sobre a renda: pressupostos constitucionais. São Paulo: Malheiros, 1997.

GRECO, Marco Aurélio; ROCHA, Sergio André. Manual de Direito Tributário Internacional. São Paulo: Dialética, 2012.

GRECO, Marco Aurélio. Planejamento Tributário. São Paulo: Dialética, 2004.

HIGUCHI, Hiromi. Imposto de Renda das Empresas: Interpretação Prática. São Paulo: IR Publicações, 2013.

MACHADO, Hugo de Brito. Comentários ao Código Tributário Nacional. $2^{a}$ ed.. São Paulo: Atlas, 2007.

MENEZES, Mauricio Moreira Mendonça de. Reflexões sobre o regime jurídico da coligação societária e a transferência de tecnologia entre sociedades coligadas. 2006.

PEREIRA, Roberto Codorniz Leite. O regime brasileiro de tributação de lucros auferidos por controladas e coligadas no exterior: um estudo empírico sobre as suas causas e efeitos. Mestrado em Direito na Escola de Direito de São Paulo da Fundação Getulio Vargas. São Paulo, 2012.

TÔRRES, Heleno Taveira. Tributação de controladas e coligadas no exterior. São Paulo: Fiscosoft, 2012. 
TÔRRES, Heleno Taveira. Princípio da Territorialidade e tributação de não-residentes no Brasil. Prestações de serviços no exterior. Fonte de produção e fonte de pagamento. In: TÔRRES, Heleno Taveira. Direito tributário internacional aplicado. São Paulo: Quartier Latin, 2003.

TORRES, Ricardo Lobo. Planejamento Tributário - Elisão Abusiva e Evasão Fiscal. São Paulo: Elsevier, 2012.

XAVIER, Alberto. A tributação dos lucros de controladas e coligadas de empresas brasileiras no exterior e os tratados contra a dupla tributação. In: Revista Tributária e de Finanças Públicas, n 3, ano 3. Almedina, 2010.

STF, ADI n 2.588, Rel. Min. Ellen Gracie.

STF, RE nº 541.090, Rel. Joaquim Barbosa.

STF, RE nº 611.586, Rel. Joaquim Barbosa.

Primeiro Conselho de Contribuintes, Primeira Câmara, Acórdão no 10197.070, Rel. Sandra Maria Faroni.

Conselho Administrativo de Recursos Fiscais. $1^{a}$ Seção de Julgamento. $4^{\mathrm{a}}$ Câmara. $2^{\mathrm{a}}$ Turma Ordinária, Acórdão nº 140.200.391. 